\title{
High School Students' Process of Construction of the Knowledge of the Greatest Integer Function
}

\begin{abstract}
Murat ALTUN $^{*} \quad$ Aslihan YILMAZ ${ }^{* *}$
ABSTRACT.During the last decade, learning theories have undergone some considerable changes based on the scientific developments about cognitive processes. In consideration of constructivist learning and process of abstraction, which came up as a result of such developments, this study investigates high schools students' skills of acquiring knowledge of the greatest integer function. It was carried out using the case study method as a group work with two volunteer high school students. In conformity with the principles of constructivist learning, the students were asked to solve three sequential problems which are suitable for observing the actions in abstraction processes and giving students the chance to use their previous experiences and knowledge as much as possible. It was observed that the students used the knowledge they had gained from the first problem to solve the others and they properly acquired the knowledge of piecewise continuous function and the greatest integer function. Another finding is that the use of cases and problems from real life to teach about functions can make a strong contribution to the use of abstraction.

Key Words: Constructivist Learning, Construction of Knowledge, Process of Abstraction, the Greatest Integer Function, Piecewise Continuous Function
\end{abstract}

\footnotetext{
* Prof. Dr.Uludağ University, Faculty of Education, maltun@uludag.edu.tr

** Uludağ University, Institute of Social Sciences, aslihan84@gmail.com
} 


\section{SUMMARY}

Purpose and Significance: This study reports about a teaching experiment done in consideration of the constructivist theory and the process of knowledge construction during that experiment. The subject matter was chosen as "the greatest integer function" and besides the basic principles of constructivism; the conduct of the study was predicated on the perception of mathematics as the knowledge and skills acquired in problem-solving processes based on modelling of reality (De Corte, 2004) and the definition of mathematics as an abstracted form of life. The major aim of the study was to design a learning environment where students can acquire meaningful mathematical knowledge and discover clues that can be used to enhance the quality of teaching throughout the process.

Methods: This study is a case study and thus, a qualitative one. It was carried out as a group work with two volunteer first grade high school students. They had not acquired any knowledge of the greatest integer function yet and what they knew about functions comprised their knowledge of definition set, value set, matching, doubles of real numbers, system of coordinates and matches between real number doubles and points in the plane. The students were asked three sequential problems aiming to help them to have an idea of the greatest integer function and draw graphics in the end. The efforts of the students to solve the problems were observed by the researchers and they were recorded all throughout the study with their permission. It was examined whether the instruction was given in harmony with the constructivist theory and in what ways the knowledge construction processes took place.

Results: The students worked on all of the problems of the study and had correct results. It was observed that the students tried to solve the problems using the structures they had reached solving the previous ones and they had the correct solutions in a shorter time. The periods of time spent to solve the $1^{\text {st }}, 2^{\text {nd }}$ and $3^{\text {rd }}$ problems are 12,8 and 6 minutes respectively. Recognition, building-with and construction, which are the defined epistemic actions of the process of abstraction, were observed dialectically and the students were found to construct the new structures about the concepts of piecewise continuous function and the greatest integer function. They were asked to make denominations considering the qualities of the graphics and they proposed the names "price chart, distance chart and numbers of steps according to distances" respectively.

Discussion and Conclusions: At this stage of the study, the students noticed that the concept of functions they had perceived to be as a straight 
line can also be piecewise. This can be construed as a construction of a new structure since the concept of functions had expanded in their minds. The speed of work and the actions of recognition and building-with observed in the dialogues during the time when the students tried to solve the "iron sticks" problem asked about the greatest integer function show that the first and second problems had provided some suitable structures which are used to solve the third problem.

When choosing the problems, the aim was to involve common real life situations in the first place and make some rare applications of mathematics the extensions of common ones. This was later seen to have been achieved, whereupon the second and third problems were solved in a shorter time than the first one had been solved in. The dialogues held when teaching about the problems show that the students constructed knowledge discussing with one another. Considering all these, it is possible to mention that the instruction was given in a problem-based way and in harmony with constructivist learning.

As can be understood from the graphics as well, the concepts of piecewise continuous function and the greatest integer function were abstracted to some extent in this study. Besides, the studies on the solutions of the first and second problems were not enough for students' proposing the name "piecewise continuous function" or any similar one for the new structure. Considering cognitive psychologists' definition of abstraction, which is the extraction of commonalties from a set of concrete exemplars and the corresponding categorization as the main features of abstraction (Hershkowitz et al, 2001), it can be understood that the abstraction in question is far from a classification. A study of similar examples could produce an abstraction at a higher level. These results suggest that a combined form of cognitive and dialectical approaches could explain abstraction even better. 


\title{
Lise Öğrencilerinin Tam Değer Fonksiyonu Bilgisini Oluşturma Süreci
}

\begin{abstract}
Murat ALTUN* Aslıhan YILMAZ**
ÖZ. Son on yılda öğrenme kuramlarında, çoğunlukla bilişsel süreçlerle ilgili bilimsel gelişmeleri temel alan ciddi değişiklikler olmuştur. Bu çalışmada, bu tür gelişmelerin sonucunda ortaya çıkan yapılandırmacı öğrenme ve bilginin soyutlanma süreci referans alınarak, lise öğrencilerinin Tam Değer Fonksiyonu bilgisini oluşturma süreçleri incelenmiştir. Örnek olay yönteminin kullanıldığg bu çalışma, gönüllü iki lise öğrencisiyle grup çalışması şeklinde yürütülmüştür. Öğretimde yapılandırmacı öğrenmenin ilkelerine uygun olarak, öğrencilerin ön deneyim ve bilgileri azami ölçüde kullanabildikleri, soyutlama sürecindeki eylemlerin gözlenebilmesine uygun tasarlanmış üç problem, sıralı olarak kullanılmıştır. Çalışmada öğrencilerin ilk problemde oluşturdukları bilgiyi, sonrakilerde de kullandıkları Parçalı Fonksiyon ve Tam Değer Fonksiyonu bilgisini belirli bir seviyede doğru olarak oluşturabildikleri gözlenmiştir. Çalışma ayrıca, fonksiyonların öğretiminde çevresel olay ve problemlerin kullanılmasının soyutlamaya olan güçlü katkısını ortaya koymuştur.
\end{abstract}

Anahtar Sözcükler: Yapılandırmacı öğrenme, Bilgi oluşturma, Soyutlama süreci, Tam değer fonksiyonu, Parçalı fonksiyonlar.

* Prof. Dr. Uludağ Üniversitesi, Eğitim Fakültesi, maltun@uludag.edu.tr

** Uludağ Üniversitesi, Sosyal Bilimler Enstitüsü, aslihanyilmaz-@hotmail.com 


\section{GíRISS}

Son y1llarda öğrenme kuramlarında, çoğunlukla bilişsel süreçlerin açıklanmasıyla ilgili gelişmeleri temel alan önemli değişiklikler olmuştur. Buna rağmen iyi bir öğrenmenin ne olduğu ve buna uygun öğrenme ortamının nasıl hazırlanabileceği hususundaki bilgi hala kesinlik kazanmamıştır (Schoenfeld, 1988). Buna bağlı olarak değişik öğrenme kuramları geliştirilmekte, çeşitli öğretim yöntem ve teknikleri denenmektedir (Glasersfeld, 2007). Günümüzde eğitim öğretim faaliyetlerindeki etkisini çokça hissettiğimiz yapılandırmacı öğrenme kuramı da bunlardan biridir ve temel dayanağ "bilginin dış dünyada bireyden bağımsız olarak var olmadı̆ğ ve bilginin bireyin zihnine birileri tarafindan aktarlmadĭğ, bunun aksine kendisi tarafindan yapılandırıldı ğı" (Doolittle, 1999) düşüncesidir. Buna bağlı olarak, bireyin bilgiyi nasıl yapılandırdığ 1 , yapılandırma sürecinde nelerin etkili olduğu, ne tür koşulların, bilginin niteliğini arttırabileceği gibi hususlar, öğrenme alanının önemli araştırma konuları haline gelmiştir. $\mathrm{Bu}$ alandaki çalışmalar, öğrenme, öğretim, bilgi oluşturma, soyutlama, soyutlama süreci gibi deyimlerle karşımıza çıkmaktadır.

Yapılandırmacı kuramın temelleri Piaget tarafindan yaklaşık 60 yıl önce atılmış (Fosnet ve Perry, 2007) ve alanda yürütülen araştırmalarla yapılandırmacılık kuramı ve öğretim uygulamaları çeşitlenmiştir. Bu çeşitlenmelerin kaynă̆ında, bilişsel ve sosyo-kültürel yaklaşım olarak bilinen iki yaklaşım vardır (Cobb, 1994).

Piaget ve diğer bazı biliş kuramcılarının benimsediği bilişsel görüşün temelinde, öğrencilerin kendi öğrenme tarzlarını oluşturdukları ve onların farklı yorumlarının, kazandıkları bilginin şekil ve niteliğini belirlediği düşüncesi vardır. Vygotsky ve Dayvdov'un düşüncelerini temel alan sosyokültürel görüş, bilginin birlikte yaşayışın bir sonucu olarak ortaya çıktığını savunur ve bilgi oluşturmada sosyal ve kültürel süreçlerin, öğretim etkinliklerinin önemini vurgular (Cobb, 1994; Tomic ve Nelissen, 1998).

Sosyo-kültürel görüş bilgi oluşturmada etkinlik temelli sosyal ve kültürel süreçleri birinci plana alır ve bilginin bireylerin çevresiyle etkileşimi içinde ortaya çıktığını savunur. Bilişsel kuramcılar ise bireyi ve onun niteliklerini birinci planda, sosyal ve kültürel etkinlikleri ikinci planda tutar. Sosyal iletişimi ve grup içi çalışmaları da göz ardı etmez. Onları derin düşünmeye yol açmak suretiyle bilgi oluşturmaya katkı verdikleri savıyla önemli bulurlar (Doolittle, 1999). $\mathrm{Bu}$ düşünce farklılıkları yapılandırmacılığın bilişsel, sosyal ve radikal vb gibi çeşitli formlarının tanımlanmasına yol açmıştır. 
Bu çalışmada, yapılandırmacı kurama uygun bir öğretim denemesi ve bu deneme sırasındaki bilgi oluşturma süreci rapor edilmektedir. Çalışmanın yürütülmesinde, yapılandırmacılığın yukarıda açıklanan anlamı, matematiğin eskisinden farklı olarak ögrenilmesi gereken soyut kavramlarin ve becerilerin bir koleksiyonu değil, gerçekliğin modellenmesini temel alan problem çözme ve anlamlandırma süreci ile oluşan bilgi ve yine bu süreç içinde gelişen beceriler (De Corte, 2004) olarak algılanması ve yine matematiğin, en sade şekilde, "yaşamın bir soyutlanmış biçimi" şeklindeki tanımlanması esas alınmıştır.

$\mathrm{Bu}$ düşünceler, çalışma için üç temel referans ortaya koymaktadır. Bunlar;

- Öğretim çalışmalarının problem çözme tabanlı olması,

- Gerçek yaşamdan seçilen bir model üzerinde çalışılması ve

- Süreç içinde soyutlamanın gerçekleşmesidir.

Çalışmada konu olarak Tam Değer Fonksiyonu seçilmiştir. Öncelikli amacımız, öğrencilerin anlamlı matematik bilgi oluşturabilecekleri bir öğrenme ortamı tasarlamak ve tasarlanan öğretimi uygulamaktır. Daha sonra öğretimi rapor edip, süreç boyunca öğretimin niteliğini arttırmada kullanılabilecek ipuçları yakalamaktır. Çalışmayı gerçekleştirmek için yukarıda belirlenen üç temel düşünce dikkate alınarak hazırlanan bir öğrenme ortamında, Tam Değer Fonksiyonu bilgisinin öğretimi yapılmıştır. Öğretim iki kişilik bir öğrenci grubuna verilmiştir.

Çalışmanın dayandığı temel kavramlardan soyutlama, en sade şekliyle, "somuttan soyuta geçiş süreci" olarak bilinir. Soyutlama öncelikle bilgi kuramcılarının ilgilendiği bir kavram iken, öğrenme süreci üzerindeki çalışmaların yoğunlaşması üzerine, eğitim kuramcılarının da ilgisini çekmiş ve araştırılan tartışılan bir kavram olmuştur. Soyutlama kavramı üzerindeki tartışmalar yapılandırmacı kuram üzerindeki tartışmalara paralel olmuş ve bilişsel yapılandırmacılar ile sosyo-kültürel yapılandırmacıların soyutlamayı açıklama yaklaşımlarında farklılıklar ortaya çıkmıştır. Piaget ve onu izleyen diğer bilişsel yaklaşım kuramcıları soyutlamanın bir dizi matematiksel süreç ve nesneden oluştuğunu, öğrencilerin zihinlerindeki bu nesneleri ortak özelliklerine göre ilişkilendirmek suretiyle daha ileri bir matematiksel nesneye ulaştıklarını belirtmişlerdir (Hershkowitz, Schwarz ve Dreyfus, 2001). Soyutlama yapan bireyde, üzerinde çalışlan nesnelere göre daha yüksek seviyede bir nesnenin olabileceği sezgisi vardır ve bir sınıflama yapmak suretiyle bu (yeni yapıya) nesneye ulaşılır. Bu yaklaşımı savunanlar, soyutlamanın öğretim sırasında örneklerin incelenmesi ve onlardaki ortak 
özelliklerin yakalanması ile gerçekleştiğini belirtmişlerdir (Özmantar, 2004; Yeşildere ve Türnüklü, 2008). Piaget'nin de içinde bulunduğu bu psikologlar, soyutlamanın doğrusal olduğunu ve siralı eylemler sonucunda elde edildiğini savunmuştur. Soyutlama düzeyi, bireyin kültürel çevresinden, ön deneyimlerden, öğrenme ortamından ve öğrenme konusunun sunulduğu bağlamdan etkilenir. Soyutlama süreci doğrudan gözlenebilen bir durum olmadığından (Dreyfus, 2007), soyutlama süreci hakkında bilgi verebilecek gözlenebilir eylemlerin tanımlanmasına ihtiyaç duyulmuştur.

Soyutlama kavramı ile ilgili ikinci temel açıklama; sosyo-kültürel yaklaşımın benimsendiği açıklamalardır. Bu açıklama, Davydov'un etkinlik kuramı ile ilgili düşüncelerinden beslenir. Davydov (1990)' a göre kavramanın, deneysel düşünme seviyesi ve kuramsal düşünme seviyesi olmak üzere iki şekli vardır. Bu düşünceye göre, günlük kavramlar deneysel düşünme ile kazanılır fakat deneysel düşünme ile soyut bilimsel kavramlara ulaşılamaz. Soyut bilimsel bilginin kazandırılmasının tek yolu "düşüncenin, durmayan bir devinim ve değişim içinde bulunması ve düşüncedeki evrimin iç çelişmelerinin yaşanması sonucunda ortaya çıkması" anlamına gelen diyalektik mantıktır (Hershkowitz vd, 2001). Öğrenciler yeni matematiksel bilgi ile öncekiler arasında muhtemel çelişkileri ve uygunlukları tartışır, bunların arasında bir bağ kurmaya ihtiyaç duyarlar. Özellikle kanıtlama suretiyle ulaşılan bilgilerde bu durum açıça görülür. Davydov (1990)'un yaklaşımı, bilişsel yaklaşımı reddetmekten ziyade, onu kapsamakta ve soyutlama için daha geniş bir çerçeve sunmaktadır. Davydov'un (1990) açıklamalarına göre bilişsel psikologların yaklaşımı deneysel düşünce düzeyi için uygun, kuramsal düşünce düzeyi için uygun değildir veya yetersizdir. Dolayısıyla bilimsel kavramların soyutlanması sürecinde diyalektik mantık gereklidir (Özmantar, 2004; Yeşildere ve Türnüklü, 2008).

Okulda öğrenilenlerin çoğu bilimsel düşüncelerle ilgili kavramlar olup, bunlara deneysel çalışmalarla ulaşmanın ciddi sınırlılıkları vardır. Matematiğin deneyle doğrulanabilen, ancak deneye dayanmayan bir bilim olduğu (Yıldırım, 1988, sf. 64) göz önüne alındığında bu zorluk apaçık görünür.

Soyutlama için diyalektik yaklaşımı benimseyen Hershkowitz vd. (2001), kendi deneyimlerini Davydov'un kuramı ile birleştirerek soyutlamay1 "Önceden edinilmiş matematiksel bilgilerin yeni bir matematiksel yapı oluşturmak üzere dikey olarak yeniden örgütlenmesi etkinliği" şeklinde tanımlamışlardır. Bu tanımda geçen "etkinlik" sözcüğü ile bireysel veya grup çalışmaları için tasarlanmış öğrenme ortamlarında, öğrencilerin yürüttükleri eylemler, "yeni bir matematiksel yapl" ile soyutlama sonucunda oluşan matematiksel düşünce (kavram, bağıntı veya 
genellemeler), "dikey örgütleme" ile ise Gerçekçi Matematik Eğitimi (Realistic Mathematics Education) kuramında matematikleştirme sürecinin ikinci safhası (Hershkowitz vd.; 2001) (birincisi yatay matematikleştirme), yani sembollerle çalışma, kavramlar arasında ilişkiler kurmak suretiyle mevcut matematiksel nesnelerden daha formal bir matematiksel nesneye ulaşma (De Lange, 1996; Hauvel - Panhuizen, 1996) kastedilmektedir. Herskhowitz vd. (2001)'nin, yaptıkları soyutlama tanımının içerdiği başlıca epistemik (bilgi oluşumu ile ilgili) eylemleri tanıma (recognizing), kullanma (building with) ve oluşturma (reconstruction) olarak tanımlanmış ve çalışmalarına sözcüklerin ilk harflerini kullanarak RBC kuramı adını vermişlerdir. $\mathrm{Bu}$ eylemlerin tanımlanmasının en temel amacı soyutlama süreci hakkında bilgi edinmektir. Bunların her biri gözlenebilir niteliktedir ve bunların gözlenmesi ile soyutlama sürecinin daha derin tanınması söz konusu olabilir. Kuşkusuz ki soyutlama sürecinin tüm bileşenleri bu eylemlerle sınırlı değildir. Öğretim programı, öğretim için tasarlanmış etkinlikler, öğrencinin deneyimleri, tarihsel ve kültürel çevre, öğrenme ortamı, öğretim araçları ile ilgili bilgi ve becerileri, sosyal çevre, öğrencinin grup içindeki konumu ve bireysel çalışma alışkanlıklarının her biri soyutlama süreci üzerinde etkisi olan faktörlerdir (Dreyfus, 2007). Bu tartışmalar, her matematiksel kavramın soyutlama sonunda elde edileceği anlamını taşımaz. Matematiksel kazanımların soyutlanma suretiyle elde edilenlerinin fazlalılı̆̆ına ve önemine rağmen, soyutlama gerektirmeyen matematiksel kazanımlarda da vardır. Örneğin, bazı matematiksel beceriler, işlem algoritmaları, hatırlanmaya ve tekrara bağlı olarak kazanılırlar.

Dreyfus (2007) epistemik eylemlerin birbirleriyle iç içe geçmiş, birbirleri içinde yuvalanmış yapısını rapor etmiştir. Bazen sıralı eylemler halinde olabilecekleri gibi, bazen biri diğerinin tamamlayıcısı, uzanımı veya aynı anda gerçekleşen paralel eylemler olabilmektedir. Epistemik eylemlerden tanıma (recognizing), bireyin önceden kazanmış olduğu formal veya informal bilgilerle, öğrenme ortamındaki matematiksel unsurlara anlam yüklemesi demektir. $\mathrm{Bu}$ anlam yükleme konuyla ilgili ve önceden karşılaşılmış bulunulan yapıları tanıma demektir. Kullanma (building with), tanımış bulunduğu matematiksel varlıkları yeni bilgi üretmeye giden yolda ilişkilendirme, problem çözmede kullanma, onlardan yararlanma anlamına gelir. Kullanma eylemi, öğrencilerin bir durumu anlama, anlamlandırma, anlatma, bir öneriyi savunma, bir varsayımda bulunma hallerinde ve bir problem çözmeyle karşı karşıya olduklarında gözlenir. Çünkü burada öğrenciler daha önceden tanıdıkları yapılara ihtiyaç duyar ve onlara başvururlar. Öğrencinin kullanma davranışı gözlemlenmediğinde (tıkanma veya duraksama halinde) öğretmen vs. onları harekete geçirmek için bir 
ipucu verebilir. Oluşturma (construction) soyutlama sürecinin ana basamağıdır. Çünkü bireyin bilgi ve deneyimleri ile diğer epistemik eylemleri gerçekleştirmesi olmaksızın yeni bir yapı oluşmaz. Oluşturma diğer iki epistemik eylemin gerçekleşmesi sonucunda ortaya çıkar (Dreyfus, 2007). Başka söyleyişle tanınan yapıların kısmi değişikliğe uğratılarak yeniden yapılandırılması ve düzenlenmesi süreci ve bunun sonucunda yeni anlamlar inşa etme oluşturma olarak ifade edilmiştir (Bikner-Ahsbahs, 2004). Oluşturmanın gözlenebilmesi, araştırmacının o alandaki bilgi derinliğini gerektirir. Ancak bu durumda kavramlardaki farklılaşma fark edilebilir. Oluşturma davranışını gösteren öğrencilerin hal ve davranışlarında değişim gözlenir, söylediklerini kanıtlama ihtiyacı duyarlar. Kullanma ile oluşturma arasındaki en önemli fark kullanmada daha önce edinilmiş (var) olan yapılar, oluşturmada ise çalışmanın hedeflediği yapılar söz konusudur. Öğrenci problemi çözmek, ispatlama yapmak suretiyle bu yeni yapıyı oluşturur. Öğrenciler sıradan problemleri çözdüklerinde tanıma ve kullanma arasında gelip giderler. Rutin olmayan problemleri çözdüklerinde çoğunlukla bir oluşturmaya gidebilirler. Oluşturma bu nedenle tanıma ve kullanmadan bağımsız değildir (Hershkowitz vd., 2001).

RBC'nin açıklanmasında başvurulan dikey deyimi, matematiksel bilginin soyutlanmasının Gerçekçi Matematik Eğitimindeki (GME) "matematikleştirme" süreci ile aynı olup olmadığını akla getirebilir. GME'yi geliştiren Freudenthal ve savunan diğer yazarlar matematiksel bilginin oluşumuna matematikleştirme (mathematization) adını vermiş ve soyutlama deyimini kullanmamışlardır (Gravemeijer, 1990). GME'de matematik "bir insan etkinliği" olarak tanıtılmakta ve matematikleştirme süreci çevresel bir olay veya durumdan matematiksel bilgiye ulaşma şeklinde tanımlanmaktadır. $\mathrm{Bu}$ süreçteki yatay ve dikey matematikleştirme süreçleri yapılandırmacı karaktere sahiptir, fakat GME'nin bilgiyi oluşturmada izlediği yol, yapılandırmacılı̆̆ın izlediği yollarla birebir örtüşmemektedir. GME'nin matematiksel bilgiyi oluşturma için sunduğu üç temel basamak (sürecin yeniden keşfi, yönlendirilmiş keşfetme ve kendi kendine gelişen modellere yer verme (Gravemeijer, 1994)), soyutlama sürecindeki epistemik eylemlerle ilişkili fakat tümüyle aynı değildir.

Dreyfus (2007), RBC kuramı ile açılanan soyutlama sürecinde oluşturulan yeni yapıların kırılgan olduğunu ve bu durumun yeni yapıyı muhafaza etmeyi zorlaştırdığını belirtmiştir. $\mathrm{Bu}$ açıdan bakıldığında soyutlamanın gerçekleşmesinin yanı sıra, edinilen yeni kavramların sağlamlaştırmaya ihtiyacı olduğunu ve bu sağlamlaştırmanın, yapıların birbirleri ile ilişkilendirmesi, onları yeni bir yapı oluştururken kullanma ve üzerlerinde yoğun bir biçimde düşünme halinde gerçekleşebileceğini 
belirtmiştir. Soyutlama sürecinde yeni yapılar oluşturulurken, öncekilerin tanınması ve kullanılması, onların daha rahatlıkla kullanılabilmesine ve sağlamlaşmasına yol açar. Dreyfus (2007) soyutlanmış bir matematiksel nesnenin sağlamlaştırma halinde ancak yeni bir yap1 olarak nitelenebileceğini belirtmiştir. RBC ile açıllanan soyutlama sürecine sağlamlaştırmanın (consolidation) eklenmesiyle, modeli $\mathrm{RBC}+\mathrm{C}$ şeklinde ifade etmiştir.

Fonksiyonlar üzerinde birçok çalışma yapılmıştır. Son dönemlerde yapılan çalı̧̧maların bir kısmı fonksiyon tanımının ve grafiğinin algılanışı (örneğin; Dede (2004), Karataş ve Güven(2004)), bir kısmı fonksiyonların bilgisayar destekli eğitimle öğretimi (örneğin; Baki ve Öztekin (2003), Güveli ve Güveli (2002), Verdoolaege ve Woods (2008)), bir k1smı da fonksiyon bilgisinin soyutlanma süreci ile ilgilidir. Bunlardan konuya olan yakın ilgisi bakımından fonksiyonlar ve soyutlama süreci ile ilgili olanlar aşağıda özetlenmiştir.

Hershkowitz vd. (2001) dokuzuncu sınıfa giden bir öğrenci ile yaptıkları ve soyutlama sürecinin bir analizini amaçlayan çalışmalarında, soyutlamanın problem çözme esnasında oluştuğu düşüncesini ileri sürmüşlerdir. Örnek olay incelemesi yönteminin kullanıldığ hayvanat bahçesindeki üç hayvan topluluğunun zamana bağlı gelişimi üzerinde geliştirilen dört açık uçlu soru kullanılmıştır. Video kaydı altında gerçekleştirilen görüşmede öğrenci bazı sorularda daha önceden yapılandırmış olduğu, fonksiyon kavramı bilgisini kullanarak yeni bilgiyi yapılandırmaya ihtiyaç duymamış, tanıma eylemi ile yetinmiş̧ir. İlerleyen sorularda üç topluluğun grafiklerini kullanmak zorunda olduğu ancak bir topluluğun sayısının değişme davranışı göstereceği bir durum söz konusu olmuştur. Öğrenci, bu durumu onu şaşırtan bir problem halinde ortaya koyup, mantıksal yapıyı tanımış ve uygun bilgi ile yeniden düzenleyerek kullanma eylemini gerçekleştirmiştir. Diğer sorularda zorlandığı görülen öğrenciye, görüşmeci tarafından basit tekrar soruları yöneltilmiş, böylece öğrenciye basit bilgi yapıları hatırlatılarak öğrencinin kendince yeni bilgi yapılarını inşa edebilmesine olanak tanınmıştır. Çözüm sürecinin sonunda, öğrenci problemdeki sayısal verilerin değişim oranını fonksiyonel bir kavram olarak yapılandırmış, kısmen de olsa oluşturma eylemini göstermiştir.

Özmantar (2004), 17 yaşındaki iki öğrenci ile $y=f(|x|)$ fonksiyonu üzerinde yürüttüğü çalışma ile soyutlamanın gözlenebilen dört parametresi olarak, kavramsal çatı, öğrenci, işlemler ve hedefleri belirtmiş ve 
soyutlamanın bu dört parametrenin dinamik ve diyalektik etkileşimi ile ortaya çıktığını ifade etmiştir.

Monaghan ve Özmantar (2006), bir öğrenci üzerinde yürüttükleri nitel bir çalışmada $y=f(x), \quad y=f(|x|), \quad y=|f(x)| \quad$ ve $\quad y=|f(|x|)|$ fonksiyonları üzerinde, birinden yararlanarak diğerini oluşturma sürecini ve matematiksel yapılar arasındaki ilişkileri incelemişlerdir. Soyutlanmış bir matematiksel nesnenin kırılgan olduğunu ve onun ancak başka bir yapının oluşturulmasında kullanıldığı takdirde sağlamlaşabileceğini ve yeni bir yapının sağlamlaştırılmış formunun ancak matematiksel yap1 olarak ele alınabileceğini belirtmişlerdir.

Özmantar ve Monaghan (2007) mutlak değer fonksiyonunu $(y=|f(x)|)$ konu alan deneysel bir çalışma ile arkadaşla iletişime geçebildiği ve öğretmen yardımının alınabildiği bir ortamda, soyutlama sürecini incelemişlerdir. Bu çalışmada, soyutlama süreci ile ilgili olarak, $(i)$ insan ve maddenin aracılığ1, (ii) matematiksel yorumlama için öğretmen yardımı veya yönlendirmesi, (iii) öğrencilerin gelişim düzeylerine uygun diyalektik ortam ve $(i v)$ soyutlanacak birşeyin varlığı olmak üzere dört önemli bileşen ortaya koymuşlardır.

Yeşildere (2006) ile Yeşildere ve Türnüklü (2008) tarafından 6., 7. ve 8. sınıf öğrencilerinde problem çözme sırasındaki soyutlama sürecinin matematiksel güce göre farklılaşıp farklılaşmadığını incelenmişlerdir.

Yeşildere (2006), farklı matematiksel güce sahip 6., 7. ve 8. sınıf öğrencilerinin matematiksel düşünme ve bilgi oluşturma süreçlerini incelemiş ve matematiksel gücü yüksek yapan faktörleri tartışmıştır. $\mathrm{Bu}$ çalışmada yüksek matematiksel güce sahip öğrencilerin, düşük olanlara göre, soyutlama sürecinde tanıma, kullanma ve oluşturma eylemlerinde daha başarılı oldukları sonucuna varılmıştır.

Yeşildere ve Türnüklü (2008) farklı matematiksel güce sahip sekizinci sınıf öğrencilerinin bilgi oluşturma süreçlerini RBC kuramı ışığında incelemişlerdir. Örnek olay incelemesi yönteminin kullanıldığı ve matematiksel gücü düşük olan 2, matematiksel gücü yüksek olan 2 olmak üzere toplam dört öğrenci ile yürütülen bu çalışmada ikizkenar bir üçgende tabanda alınan bir noktadan kenarlara indirilen dikmelerin uzunlukları ile ikizkenarlara ait dikmenin uzunluğu arasındaki ilişki problemi kullanılmıştır. Matematiksel güç düzeyi düşük veya yüksek olan öğrenciler arasındaki temel fark, öğrencilerin daha önceden yapılandırmış oldukları bilgi yapılarının doğruluğu veya yanlışlığından kaynaklanmıştır. Problem çözme 
sürecinde verilen ipucu ile önceden oluşturulmuş yapının hatırlanmasını içeren tanıma eyleminde, düşük ve yüksek matematiksel güce sahip öğrencilerin ipucunu değerlendirme ve çözüme ulaşmalarında farklılıklar ortaya çıkmıştır. Matematiksel gücü yüksek olan öğrenciler, ipuçları sayesinde hatalarını fark edip, doğru sonuca gitmek için kullanırlarken, matematiksel gücü düşük olan öğrenciler ipuçlarını fark edememiş ve kullanma eylemini gösterememişlerdir.

$\mathrm{Bu}$ çalışmanın konusu olarak seçilen Tam Değer Fonksiyonu ve aynı türden sayllabilecek diğer parçalı fonksiyonlar, lise matematiğinde önemli bir yer tutmaktadır. Fonksiyon konusuna ortaöğretim matematik programında bağıntı, fonksiyon ve işlem kavramları için 9. sinıfta 24 saat, üstel fonksiyon ve logaritma fonksiyonu için 11. sinıfta 22 saat ve fonksiyon, parçalı fonksiyon ile mutlak değer fonksiyonu için 12. sınıfta 16 saat süre ayrılmıştır (Milli Eğitim Bakanlığı, 2008). Bu çalışma ile Tam Değer Fonksiyonu için bir öğretim şekli önerilecek ve bilgi oluşturma sürecinin bir tahlili yapılmış olacaktır.

Yukarıda özetlenen çalışmalardan Monaghan ve Özmantar'ın (2004) çalıştıkları mutlak değer fonksiyonu ve grafiğinin çizimi problemine, doğrudan bir matematik kavramla karşılaştıkları için her öğrencinin ilgi duyması beklenemez. Bu çalışmada olduğu gibi sosyal bir değer taşıyan problemler soyut matematik problemlerine göre daha çok ilgi çekerler. Hershkowitz vd (2001)'in konusu olan hayvanat bahçesindeki hayvan topluluklarının değişimi de öğrencilerin yaşamından kısmen uzaktır. Yeşildere ve Türnüklü'nün (2008) çalışmasını üzerinde yürüttüğü üçgende dikme problemi daha çok matematiksel kanıtlamaya yatkın öğrencilerin ilgi duyacağı bir konudur. Problemin sunulduğu bağlam, öğrencide probleme ilgi duyma ve onu değerli bulma açısından önemlidir. Bizim çalışmamızın problemlerinin seçiminde, öğrencilere anlamlı gelebilecek, onu çözmeyi değerli bulabilecekleri umulan bağlamlar kullanılmıştır. Ayrıca çalışma, Özmantar ve Monaghan'ın (2007) soyutlama sürecinin bileşenlerinden biri olarak rapor ettiği "soyutlanacak bir matematiksel varlı̆̆ın olması" bakımından açık örnekler üzerinde yürütülmüştür. Bu yönüyle de soyutlama sürecini daha açık göstermesi beklenebilir. Ayrıca bu çalışma içerdiği iki tür fonksiyonun yapılandırmacı yaklaşımla öğretimini sunması ve soyutlama sürecinin yapılandırmacı yaklaşıma göre düzenlenmiş bir öğrenme ortamında izlenmesine firsat vermesi açısından diğerlerine göre farklılık göstermektedir. 


\section{YÖNTEM}

\section{Araștırma Modeli}

Bu araştırma, bir "örnek olay incelemesi"dir ve bu yönüyle de bir nitel araştırmadır. Örnek olay incelemesi; güncel bir olguyu kendi gerçek yaşam çerçevesi (içeriği) içinde çalışan, olgu ve içinde bulunduğu içerik arasındaki sınırların kesin hatlarıyla belirgin olmadığ ve birden fazla kanıt veya veri kaynağının mevcut olduğu durumlarda kullanılan görgül bir araştırma yöntemidir (Yıldırım ve Şimşek, 2006, s.277). Örnek olay incelemesinde ve nitel araştırmalarda araştırmacı nicel çalışmalarda olduğu gibi sadece araştırma konusunu gözleyen değil, aynı zamanda konuyu ve katılımcıları daha iyi anlayıp analiz edebilmek için çalışmaya bizzat katılan, katılımcılarla birebir görüşen kişi konumundadır, yani sürecin bir parçasıdır. Bundan dolayı araştırmacı çalışmaya katılımcı gözlemci konumunda dahil olmuştur. Katılımcılara günlük hayatta karşılaşma ihtimallerinin fazla olduğu alanlardan, konuya ilişkin "Bu olay size tanıdık mıdır? Otoparka araç bırakma işi?, Daha önce kargo ile herhangi bir eşya yolladınız mı?" şeklinde sorular önceden hazırlanmıştır. Bu çalışmada temel hedef tam değer fonksiyonu olmasına rağmen parçalı fonksiyon ile ilgili sorular da alt yapı oluşturmak amacıyla araştırmacılar tarafından çalışmanın ilk kısmı olarak düşünülmüştür.

\section{Çalışma Grubu}

$\mathrm{Bu}$ araştırma, bir lisenin birinci sınıf öğrencileri arasından bu çalışmaya gönüllü olarak katılmak isteyen iki öğrenci ile birlikte, grup çalışması şeklinde yapılmıştır. Öğrencilerin matematik başarıları için ayrı bir sınav yapılmamış, okul yönetimi ve matematik öğretmenleri ile görüşülmüştür. Dönem başarı notları 5 olup, öğretmenleri tarafindan da başarılı olarak bilinen öğrencilerdir. Tam Değer Fonksiyonu veya benzerleri ile karşılaşmış olma şansını azaltmak için lise 1. sınıf olmaları tercih edilmiştir. Öğrencilerin her ikisi de okul veya dershanede Tam Değer Fonksiyon bilgisi almamış olup, fonksiyon konusuna ilişkin bilgileri, sekizinci ve dokuzuncu sınıf programlarının içeriğine uygun tanım kümesi, değer kümesi, eşleme, reel sayı ikilileri, koordinat sistemi, reel ikililerle düzlemin noktaları arasındaki birebir eşlemeden ibarettir.

\section{Örnek Olay Çalışması}

$\mathrm{Bu}$ çalışmada öğrencilerin yapılandırmacı öğrenmeye uygun tasarlanmış bir öğrenme ortamında, bilgi oluşturma süreci üzerinde durulmuştur. Öğrencilerin bilgi oluşturma süreçlerini incelemede RBC kuramı referans alınmıştır. RBC'nin epistemik eylemleri olarak bilinen 
tanıma, kullanma ve oluşturma eylemleri, sürecin diyalektik yapısı dikkate alınarak, her bir problemin çözümünde birlikte gözlenmiş ve kaydedilmiştir. Çalışmada ayrıca Tam Değer Fonksiyonu ve gerektirdiği ön yapıların, öğrenciler tarafından ne ölçüde oluşturulduğu rapor edilmiştir.

Görüşmelerden önce, okul yönetiminden ve öğrencilerden izin alınmış, çalışmanın amaç ve kapsamı okul yönetimine ayrıntılı şekilde anlatılmıştır. Çalışma grubundaki ögrencilere çalışmanın kayıt altına alınacağı belirtilmiş ve öğrencilerden sözlü izin alınmıştır. Çalışmanın, ders başarı notları ile herhangi bir ilgisi olmadığı, doğru veya yanlış cevaba ulaşmaktan çok, o cevaba ulaşma sürecinin incelenmesinin amaçlandığı açıklanmıştır.

\section{Verilerin Toplanması}

Araştırmada gözlem, görüşme ve doküman incelemesi gibi nitel veri toplama yöntemleri bir arada kullanılmıştır. $\mathrm{Bu}$ üç yöntemin bir arada kullanılması, "veri çeşitlemesi (triangulation)" olgusuna bir örnektir. Yıldırım ve Şimşek (2006) çeşitlemede temel ilkenin, farklı bireyler ve ortamlardan farklı yöntemlerle veri toplamak ve bu şekilde sonuçlarda ortaya çıkabilecek ön yargıların ya da yanlış anlamaların önüne geçmek olduğunu belirtmektedir (Koçbeker ve Saban, 2005). Verilerin toplanması ve analizinde video kamera ve bilgisayar kullanılmıştır.

Görüşme iki öğrenciyle aynı anda ve aynı ortamda gerçekleşmiştir. Burada amaç öğrencilerin akran yardımı alarak ve aralarında konuyu konuşmalarına firsat tanıyarak sesli düşünmelerini sağlamaktır. Öğrencilerin problemler üzerindeki çalışmaları, kendilerinin bilgisi ve izni altında ses ve görüntü kaydı altında gerçekleşmiştir. Çalışmanın başında, problemlerin içinde sunulduğu bağlamı tanıma ile ilgili soru ve açıklamalar kullanılmış, çözüm sırasında, duruma göre öğrencilerin düşüncelerini açığa çıkarmak için gerekli sorular yöneltilmiş, öğrencilerin birbirleriyle ve araştırmacılarla olan sözlü ve sözsüz iletişimi gözlenmiş̧ir. Daha sonra görüntü ve ses kayıtları bu çalışmanın hedefleri olarak belirlenen yapılandırmacı öğrenmenin gerçekleşmesi ve bilgi oluşturma süreci bakımından analiz edilmiştir.

Öğrencilerin çalışması sırasında araştırmacılar veriye ilk elden ulaşma olanağını sağlamak üzere gözlem yapmıştır. Bir araştırmacı gözlem yapmak ve görüşmeyi kaydetmek üzere çalışma ortamında bulunurken, diğer araştırmacı görüşmeye "katılımcı gözlem" yöntemi ile dahil olmuştur.

Analiz edilen dokümanlar öğrencilerin problemleri çözdüğü çalışma ve karalama kă̆ıtları ile görüşme sırasında kaydedilen videodur. 


\section{Veri Toplama Araçları}

$\mathrm{Bu}$ çalışmanın veri toplama araçları, örnek olay çalışmasının üzerinde yürütüldüğü problemlerin bulunduğu çalışma kağıtlarıdır. Bunlar üç tane olup, ilk ikisi parçalı fonksiyon, üçüncüsü Tam Değer Fonksiyonu ile ilgilidir. Tam Değer Fonksiyonunun parçalı fonksiyonların idealize edilmiş bir formu olduğu göz önüne alınarak hedef kavramın gerektirdiği ön bilgileri oluşturmak üzere önce parçalı fonksiyona uygun davranan olayları konu edinen iki problem yöneltilmiştir. Problem seçiminde ve türlerinin düzenlenmesinde klinik görüşmelerden beklenen sonuçları alabilmek için $(i)$ tartışmaya elverişli, (ii) açık uçlu, (iii) öğrencilerin düşünme seviyelerini açıklığa kavuşturacak fırsatlar sunması gibi özellikler (Tanışlı, 2008) aranmıştır. Problemler öğretimde kullanıldıkları sırayla aşağıda verilmiştir.

- Park Problemi. Bir otopark aşağıdaki fiyat tablosuna göre park ücreti alıyor. Bu tablodaki bilgileri gösterebilecek bir grafik çiziniz. Öyle ki müşteriler bu grafiğe bakarak ödemeleri gereken parayı anlayabilsinler.

Fiyat Tablosu

$\begin{array}{lc}1 \text { saate kadar } & 4 \text { lira } \\ 2 \text { saate kadar } & 6 \text { lira } \\ 4 \text { saate kadar } & 7 \text { lira } \\ 10 \text { saate kadar } & 10 \text { lira } \\ 24 \text { saate kadar } & 12 \text { lira }\end{array}$

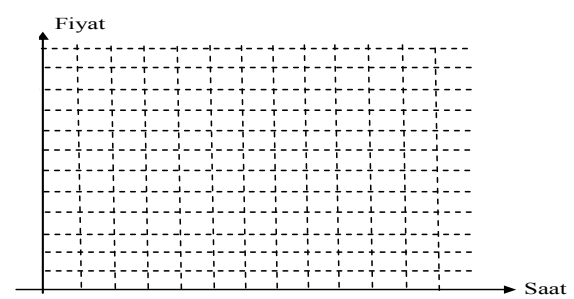

- Kargo Problemi. Bir kargo şirketi taşıdığı eşyanın bir kilogramı için, taşıma fiyatını bulurken bulunduğu merkezden, $100 \mathrm{~km}$ ye kadar mesafede olan yerlere gönderilen eşya için 5 lira, 200 ile $500 \mathrm{~km}$ arasındaki yerler için 8 lira ve daha uzak yerler için 10 lira alacak şekilde bir işlem uyguluyor. $\mathrm{Bu}$ kargo şirketinin uyguladığı fiyatları koordinat sisteminde işaretleyiniz ve eşya-fiyat grafiğini çiziniz. Grafiğinize bakan bir kimse, herhangi bir mesafeye gönderilen bir kilogramlık paket için kaç lira ödeneceğini anlayabilmelidir.

- Demir Çubuklar Problemi. Bir demirci muhtelif boylardaki demir çubukları 1'er metre boyunda kesmek suretiyle masa ayakları elde etmek istiyor. Elinde 4,5m, 3m, 4,42m, 3,10m, 1,19m, 3,05m, 4.98m, 4m, $2 \mathrm{~m}$, $4,20 \mathrm{~m}, 1,45 \mathrm{~m}, 4,55 \mathrm{~m}, 2,95 \mathrm{~m}, 4,05 \mathrm{~m}, 4,65 \mathrm{~m}, 3 \mathrm{~m}, 0,73 \mathrm{~m}, 0,15 \mathrm{~m}, 6,34 \mathrm{~m}$, $4,87 \mathrm{~m}, 5,76 \mathrm{~m}, 4,54 \mathrm{~m}$ boylarında demirler varsa bunlardan kaç tane $1 \mathrm{~m}$ boyunda masa ayağı elde edebilir? Demirlerden çıkabilecek masa ayağı sayısını anlatmada işe yarayabilecek bir grafik çiziniz. Eğer sayılamayacak 
çoklukta demir çubuk olsaydı ve hepsi grafiğe işlenseydi, grafik ne hale gelirdi? Çizerek gösteriniz ve düşüncenizi savununuz.

$\mathrm{Bu}$ soruların her birinin düzenlenmesinde "Giriş" içinde verilen açıklamalara uygun olarak; (i) Öğrencileri problem çözme uğraşı içinde tutma, (ii) Öğrencilerin olabildiğince çok ön deneyim ve bilgilerinin harekete geçirecek olması, (iii) Soyutlamaya uygun bir konunun(konuların) varlığı özellikleri göz önüne alınmıştır.

Problemlerin her biri A4 kağıdına basılmış olarak yukarıdaki sırayla tek tek verilmiş, bir kağıttaki çalışma tamamlandıktan sonra bir diğer soruya geçilmiştir. $\mathrm{Bu}$ çalışmada seçilen üç problemden ilk ikisi kullanma ve pekiştirme eylemlerinin gözlenmesine imkan verebilmesi için benzer seçilmiştir. Bu iki problem Tam Değer Fonksiyonunu anlamaya temel oluşturabilecek parçalı fonksiyon ile ilgilidir. Yaşanan hayat bu tür parçalı fonksiyon örnekleri bakımından çokça fırsat sunmaktadır. Satışa sunulan malzemelerin boyları belli aralıkta olanlarına aynı fiyat uygulanması, ürünlerin ağırlıklarına göre, küçük, orta, büyük şeklinde sınıflanması vs. (İkinci problemde birinci problemden farklı olarak 100-200 km arası boş bırakılmıştır. Bundan amaç öğrencilerin bu veri eksiğini tanıyıp tanımayacaklarını, tanıdıkları takdirde bunu gidermek için hangi ön yapıları kullanacaklarını gözlemektir.

Üçüncü problemin Tam Değer Fonksiyonunun - eğer varsa - tam bir örneği olması düşünülmüş ve demir çubuklar probleminde karar kılınmıştır. Asansördeki 1şıkl göstergelerde, geçen süreye göre eşit aralıklarla 1,2,3... yazmas1, mutlak not verme sisteminde 10 üzerinden verilen notların 5 puan ötelenmiş hali vs. de kullanılabilirdi. Bunların içinde demir çubuklar problemi, içeriğinin daha somut olması, ek açılama istemeyecek kadar açı ifade edilmiş olmasından dolayı tercih edilmiştir.

\section{Verilerin Analizi}

Verilerin analizi ve yorumlanması nitel veri analiz türlerinden betimsel analiz ile gerçekleştirilmiştir. Araştırma sorularından, araştırmanın kavramsal çerçevesinden ve görüşme ile gözlemlerde yer alan boyutlardan yola çıkılarak bir çerçeve oluşturulmuştur. Bu çerçeveye göre verilerin hangi temalar altında düzenleneceği ve sunulacağı belirlenmiş̧tir. Belirlenen tematik çerçeveye göre veriler işlenmiştir. Daha sonra organize edilen bulgular, sistematik bir yaklaşımla daha önce geliştirilen ve kodlanan kategoriler (temalar) arasındaki anlamlı ilişkileri ortaya çıkarmak ve bazı nedensel ve açıklayıcı sonuçlara ulaşmak amacıyla incelenerek ve gerekli yerlerde doğrudan alıntılarla desteklenerek tanımlanmıştır. Son olarak da 
daha önce ayrıntılı bir biçimde tanımlanan ve sunulan bulgulara anlam kazandırmak, bu bulgular arasındaki ilişkileri açıklamak ve bir takım sonuçlar çıkarmak üzere verilere dayalı olarak yorumlar yapılmıştır. Çalışma RBC teorisi 1şığında yürütüldügü için belirlenmiş olan temalar; tanıma, kullanma ve oluşturmadır.

\section{Çalışmanın Geçerlik ve Güvenirliği}

Nitel araştırmalarda kullanılan geçerlik ve güvenirlik kavramları nicel araştırmalardaki kavramlardan farklılık göstermektedir. Lincoln ve Guba (1985) nitel araştırmaların niteliğini artırabilecek bir takım stratejiler önermektedirler (Yıldırım ve Şimşek, 2006, sf. 264). Ancak bu önerileri nicel araştırmada geleneksel olarak kabul gören ve önemli değer ölçütleri olarak ön plana çıkarılan "geçerlik" ve "güvenirlik" kavramları çerçevesinde değil nitel araştırmanın doğasına uygun olabileceğini düşündükleri alternatif kavramlarla yapmaktadırlar. $\mathrm{Bu}$ çerçevede "iç geçerlik" yerine "inandırıcılık", "dış geçerlik" yerine "aktarılabilirlik", "iç güvenirlik" yerine "tutarlık" ve "dış güvenirlik" yerine "teyit edilebilirlik" ifadelerini kullanmayı tercih etmektedirler (Yıldırım ve Şimşek, 2006, sf. 264).

Nitel araştırmalarda, araştırma boyunca sağlanan uzun süreli etkileşim, derin odaklı veri toplama, çeşitleme, uzman incelemesi ve katılımcı teyidi ile iç geçerliğin, ayrıntılı betimleme ve amaçlı örnekleme ise dış geçerliği sağlamanın ölçütleridir. Araştırmada iç geçerlik çeşitleme ve katılımcı teyidi ile sağlanmıştır. Dış geçerlik ise betimsel analizin temel özelliklerinden doğrudan alıntılar yapma ve verileri ayrıntılı yorumlayarak sağlanmıştır.

Nitel araştırmalarda güvenirlik; olgu ve olayların ortama ve zamana bağlı olarak oluşturdukları ve aynen tekrar edilmesinin mümkün olmadığ 1 göz önüne alınarak farklı bir biçimde ele alınmaktadır. Çalışma bittikten sonra birbirinden bağımsız olarak her iki araştırmacı tarafından da gözlem notları diğer araştırmacınınki ile karşılaştırılmış ve bulguların (elde edilen gözlem notlarının) birbiriyle tutarlı olduğu ortaya çıkmıştır.

\section{BULGULAR}

Demet ve Kemal ile birlikte yürütülen bu çalışmada öğrencilerin Tam Değer Fonksiyonu bilgisi oluşturma süreci, tanıma, kullanma ve oluşturma eylemleri dikkate alınarak aşağıda sunulmuştur. (D: Demet, K: Kemal, A: Araştırmac1)

Demet ve Kemal (öğrencilerin gerçek isimleri değildir) bu çalışmadaki üç problemden birincisi ile 12 dakika, ikincisi ile 8 ve üçüncüsü ile de 6 dakika olmak üzere toplam 26 dakika zaman harcamışlardır. 


\section{Sürecin Analizi}

Park Problemi

Araştırmacı park problemini içeren birinci kağıdı öğrencilere vermiş ve okumalarını istemiştir.

Demet sesli okumuş ve Kemal dikkatle dinlemiştir. Kısa süre duraklama olmuştur.

" $100^{1} \mathrm{~A}$ : Bu olay size tanıdık mıdır? Otoparka araç bırakma işi? Ailenizle bir yere gittiğinizde karşılaşmış olabilirsiniz" diyerek onları olay üzerinde düşünmeye yöneltmiştir. Bu uyarı pek etkili olmamıştır. Öğrenciler fiyat tablosundaki " 24 saate kadar 12 lira" cümlesine odaklanmışlar ve bir orantı bulma çabasına girmişlerdir.

$101 \mathrm{~K}$ : Bunu (çizgiyi kastediyor) ikiye böleceğiz, sonra devam ediyormuş gibi çizeceğiz.

102 D: Tamam da bu 12'ye 6 oluyor. Nasıl devam edebilir ki?
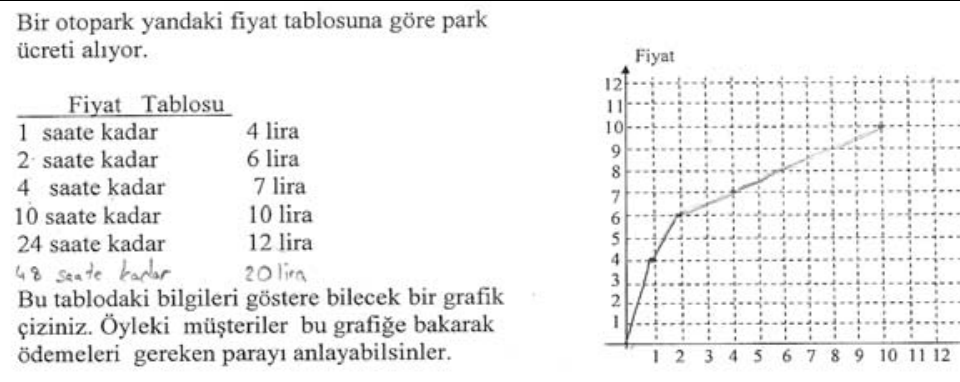

Şekil 1. Demet ve Kemal'in Park Problemi İçin Çizdikleri İlk Grafik

$103 \mathrm{~K}$ : Bunları birleştirince (çizim yapıyorlar)

104 D: Şimdi 24'e 12 olması için

$105 \mathrm{~K}$ : O zaman buraya nokta koymayacağız. Nokta buralarda bir yerde olacak. Bu devam ediyor böyle.

Öğrencilerin tabloyu doğru okudukları, koordinat sistemi, koordinat ekseni, sayı ikilisi ve ikilideki bileşenlerin sırasını, eşlendikleri noktayı

${ }^{1}$ : Diyaloglardaki numaralama, satır numaralarının homojenliğini sağlamak için 100'den başlatılmıştır. 
doğru tanıdıkları ve kullandıkları gözlenmiştir. Yanlış kullanma, grafik çiziminde görülmüştür. Alelacele merdiven basamakları şeklinde bir çizim yapmışlardır. Basamakları birbirlerine bağlamalarından grafiğin sürekli olması gerektiğini düşündükleri anlaşılmıştır. Öğrencilerin bu aşamada çizdikleri grafik Şekil 1'de gösterilmiştir.

Araştırmacı, problemdeki park olayının anlaşılmadığını fark etmiş ve probleme yeniden dönmeleri için onlarla diyaloga geçmiştir.

106 A: Şimdi böyle bir grafik yaptınız. Mesela kendi arabanızı bıraktınız. Diyelim ki aracınız otoparkta 5,5 saat kaldı, kaç lira ödeyeceksiniz ve çizdiğiniz grafik bunu gösteriyor mu? Sorunun son cümlesini tekrar okuyun. Oku Kemal.

$107 \mathrm{~K}$ : (Okuyor ve düşünüyor) ...öyle ki müşteriler bu grafiğe bakarak ödemeleri gereken parayı anlayabilsinler.

108 A: Sanki bu tablo kaybolursa adam grafiğge bakarak evet ben şu kadar ödemeliyim diyebilsin. Şimdi Kemal'in babası aracını bu parka bıraktı diyelim. Çarşı pazar alış verişiniz de 5,5 saat sürdü. Ödeyeceğiniz parayı görüyor musun?

109 D: Göremiyoruz, çünkü 5 ile 6 arasında şöyle bir şey çıkmış.

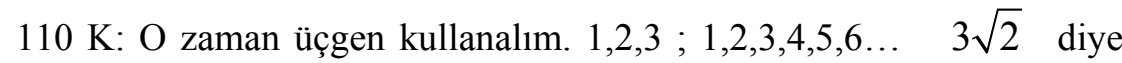
fiyat olur mu?

111 A: $3 \sqrt{2}$ diye fiyat olmaz. Siz şimdi orayı terk edin. Cevabı ben de bilmiyorum. 5,5 saat kalmış bir araba için bu tabloya bakarak kaç lira ödersiniz?

$112 \mathrm{~K}$ :Buraya bakarak 4 saate kadar 7 lira. Oradan hesaplanır da...

Son cümlede her ne kadar "hesaplanır" dedilerse de bir duraklama geçirmişlerdir. Araştırmacı aracı parka bırakma olayını bildiklerini, fiyat tablosunu tanıdıklarını fakat park parası ödeme ile ilgili ön deneyimlerinin olmadığını fark etmiş ve onlara park ücreti ödemeyle ilgili bilgi vermiştir.

113 A: Yok, yok, siz orayı bilemiyorsunuz belki, bu ne demek biliyor musunuz? Yani 4 saati geçti mi 10 saate kadar 10 lira ödeyecek. 5 saat için de 10 lira ödeyecek, 6 saat için de, 7 saat için de 10 lira ödeyecek. .Oto parka araç bırakma işini bilip bilmediğinizi ondan sormuştum. Parkta tam bu kadar kalmış diye bir orantı yok.

114 D:Yani 4 saatten sonra 10 saate kadar 10 lira.

115 A: Aynı para. 
116 D: 5 dakika geçse bile 10 lira ödüyoruz.

$117 \mathrm{~K}$ : Tamam o zaman grafik değişiyor (silmeye kalkışıyor).

118 A: Önceki grafiği silmeyin. Elinizdeki kağıtta yer var. Grafiğinizi ayrı bir yerde kendiniz üretebilirsiniz. (öğrencilerin göz ucuyla çevrelerinde cetvel araştırmaları üzerine). Cetvelsiz olabilir.

$119 \mathrm{~K}$ :Yarım saat kalınca 4 lira alacaklar yani. ... (koordinat sistemini düzenliyorlar, çizimi yapıyorlar).

120 D: Yamuk oldu bunlar (Çizimlerinden memnun olmuyor ve silmeye çalışıyorlar)

121 A: Hayır gayet güzel oluyor. Silme.

$122 \mathrm{~K}$ : Yine 4 lira ödeyecek.

123 D: $8,9,10,11 \ldots$

Öğrenciler birbirleriyle yoğun bir diyaloga girmişler ve doğru çizimi (Şekil 2) yapmışlardır.

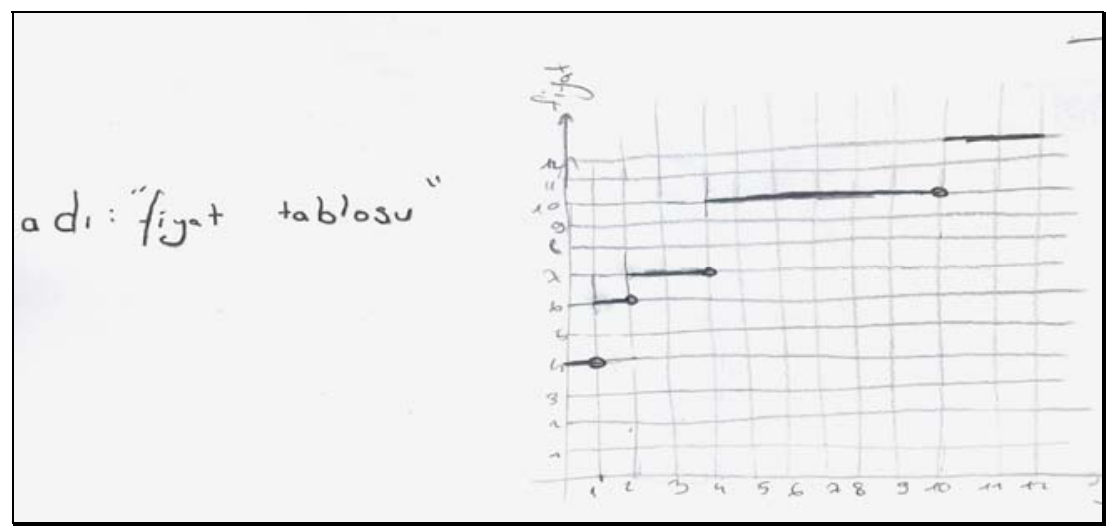

Şekil 2. Demet ve Kemal'in Park Problemi İçin Çizdikleri İkinci Grafik

Tartışma sırasında yatay çizgilerin birinin bitip diğerinin başladığ noktanın hangi fiyatla (bir üsttekiyle mi alttakiyle mi...) eşleneceğini tartışmışlar, sonra alttakine eşleneceğine karar vermişler ve doğru parçasının sağ ucunu koyulaştırmışlardır. Daha sonra grafiğin parçalı olduğunu fark etmişler ve Şekil 2'de bunu çizmişlerdir.

$124 \mathrm{~K}$ : Hayır, hayır. Bak şimdi yarım saat kalınca 4 lira ödeyecek. Ama bak burası 1,5. Bak burası düz olacak. Şurası olmayacak. Bak buras1 1,5 saat oluyor. 1,5 saat olunca 6 lira oluyor. 
125 D: Doğru doğru. O iki saatte ... 2 saat 6 lira yapacak. 2'den 4'e kadar şurası değil mi?

$126 \mathrm{~K}$ : Hayır hayır.

127 D: Evet.

$128 \mathrm{~K}$ : Bak 1,5 saat olduğu zaman 1,5 neresi? Şunun aras1, 2. kareler yani.

129 D: Yalnız 4 saate kadar dediğinde 2'nin sonunda 4'e kadar mı?(grafik üzerinde konuşuyorlar)

$130 \mathrm{~K}$ : 4'ten sonras1 10 liraya gidiyor.

131 A: 4'ten sonra kaç saat var? 10 saate kadar gidiyor.

$132 \mathrm{~K}: \mathrm{Hmmm}$, anladım.

133 D: O zaman tamam 4 saate kadar.

134 K: 2'den 4'e kadar 7 lira.

135 D: Bir saat olduğu zaman... 4 lira. Geçirdiğindeyse 6 lira.

$136 \mathrm{~K}$ : Şurada şey yok mesela, şunda 2.de 1.nin noktası yok.

137 D: Hmm, şunda bu kadar diyor. 4 ila 10 saate kadar 10 (çizim yapıyorlar). Bu yuvarlağı halk nereden bilecek?

138 K: Tam şu 10'la 4'ün kesiştiği nokta boşluk.

139 A: Neden?

140 K: Çünkü mesela 10’u 1 dakika geçse artık sonraki tarife işliyor, 12 lira yani.

141 A: 10 saate kadar diyor ama... 10 saat demiyor.

$142 \mathrm{~K}$ : Evet 10 saat yok. 10. saatte 12 lira.

143 D: O zaman buraya mı çizeceğiz yuvarlağı?

$144 \mathrm{~K}$ : Evet.

145 A: Boşluk aşağıda olacaktı. Boşluk sizin fikrinizdi yerinin çok önemi yok burada. Yorumum doğru mu?

146 D: Evet, "kadar" dediği için. Zaten 10 saatten sonrası 12 lira. Şurası (kalemle gösteriyor).

Öğrenciler, daha önce oluşturmuş bulundukları fonksiyon kavramı ile ilgili bir değişimi anlatan sürekli doğru veya ĕ̆ri çizgi şeklindeki sınırlı 
yapıda genişleme olmuştur. Öğrenciler fonksiyonun parçalı da olabileceğini hatta bu durumda uç noktalarının hangi parçaya ait olabileceği ile ilgili bir karar verme gerekliliğini fark etmişlerdir.

147 A: Peki bu tabloya bir satır eklemek ister misiniz? Yani şu 24 saatten sonra müşteri 2. gün arabasını bırakacak diyelim, ona uygun bir satır ekleyin.

148 D: O zaman grafiği uzatmak lazım.

$149 \mathrm{~K}$ : O zaman 48 yapalım. 48 saate kadar yarısıydı, bunu şimdi yarısından da düşürmemiz gerek. 20 lira olsun bence.

150 D: Olsun.

Araştırmacı parçalı fonksiyonun pekiştirilmesi amacıyla fiyat tablosuna kendilerinin bir satır eklemelerini istemiştir. Aşağıdaki diyalogdan anlaşılacağı üzere öğrenciler 48 saat için fiyat önermiş ve kendi el yazıları ile yazmışlardır (Şekil 1). Tabloda yer olmamasına rağmen grafiğin devamını doğru biçimde göstermişlerdir.

151 A: Onu da grafikte işaretleyecek olsaydınız nerede olurdu o? Tahmini olarak...(Öğrenciler grafik üzerinde doğru yeri gösteriyor). Tebrikler başardınız. Bu 12. sınıf konusuydu. Buna bir ad verecek olsaydınız ne ad verirdiniz?

$152 \mathrm{~K}$ : Fiyat tablosu.

153 A: Sevdiniz mi grafiği?

154 K: Güzel.

$\mathrm{Bu}$ şekilde oluşan yapıların kırılgan yapısını (Monaghan ve Özmantar, 2006) gidermek için oluşturulmuş bulunan yapıyı pekiştirmek amacıyla öğrencilere, parçalı fonksiyonla ilgili ikinci problem yöneltilmiştir.

Kargo Problemi

Problemi okumadan önce araştırmacı öğrencilere kargonun ne olduğunu bilip bilmediklerini, kargo ile eşya gönderip göndermediklerini sormuş ve aşağıdaki diyalogda geçen açıklamaları vermiştir. Soru kağıdında soru metni ile birlikte verilen koordinat sisteminde eksenlerin adları yazılı fakat apsis ve ordinatlar yazılmadan (boş) bırakılmıştı.

155 A: Hiç kargoyla eşya gönderdiniz mi?

156 D: Ben göndermiştim ama küçüktüm.

157 A: Problemi okuyun. 
158 D: (sesli okuyor)

159 A: Kargolar bir şeyi farklı şehirlere yollarken farklı tarifeler uygularlar. Örneğin, Bilecik'e ayrı tarife, Afyon'a ayrı tarife uygulanır. Bir sınır koyarlar. Şu kadar mesafeye kadar olan yerlere şu kadar diye. Mesela Türkiye'yi 3'e veya 4'e bölerler. Bulundukları merkezden uzaklığına göre... Bir önceki probleme benziyor mu?

(Öğrenciler araştırmaciya cevap vermeden koordinat sistemine yöneldiler ve eksenler üzerinde kalemle gezinerek)

160 D: Şimdi bu çentikleri $50 \mathrm{~km}$ mi yapsak?

$161 \mathrm{~K}$ : Tamam.

162 D: 50 yaparsak 100, 200... tamam sığıyor (koordinat eksenleri üzerinde aralıkları tasarlıyorlar)

$163 \mathrm{~K}$ : Bunu da direk 1,2,3,4... yapalım. 5, 8 bir de 10 lira var.

164 D: Şimdi ne yapıyoruz? 100 km'ye kadar mesafede 5 lira.

Öğrenciler problemi bir önceki problemde oluşturmuş bulundukları yapıları kullanarak, geciktirmeden çizimi yapmaya yönelmişlerdir. Burada öğrencilerin olayı resmedebilmek için eksen sistemi üzerinde kendilerinin çentik adını verdikleri aralıkları $50,100, \ldots$ şeklinde tasarlayıp, veri tablosu ile karşılaştırmaları, bir önceki problemde oluşturdukları bilginin burada kullanıldığını göstermiştir. Tanıma ve kullanma eylemleri düşey eksenin doldurulmasında da açıkça görülmüş, verilerdeki 5,8 ve 10 lira değerleri için eksen üzerine $1,2,3,4, \ldots, 10$ yazmanın yeterli olacağını belirtmişlerdir. Öğrencilerin koordinat sistemine bu denli hakimiyeti, onların ilgili ön yapıları pekiştirilmiş formuyla kullandıklarını göstermiştir.

$165 \mathrm{~K}: 100 \mathrm{~km}$ olunca şey oluyor yani 5 liradan çıkıyor.

166 D: Yani yine demin yaptığımız gibi(Verileri kalemle takip ederek çizime başliyorlar)

167 D: 200'le 500 arası diyor, 100 ile 200 aras1 yok.

$168 \mathrm{~K}:$ Onu atlayalım o zaman, oraya boşluk koyalım.

169 A: Nas1l, ne oluyor?

170 D: Şimdi 100 km'ye kadar 5 lira diyor, 200 ile 500 arasında 8 lira diyor. 100 ile 200 arasında fiyat yok. Oraya bir fiyat vermemiş.

$171 \mathrm{~A}$ : Çok haklısınız. Bu benim eksiğim. Tebrik ediyorum seni. Oradaki 200'ü 100 yapın. 
$172 \mathrm{~K}$ : (düzeltmeyi yapıyor)

173 D: 100 ile 500 arası 8 lira. 8'e bak (çizim yapıyorlar)

Öğrenciler bu çizimde çok istekli ve heyecanlı görünmüşlerdir. Demet'in "Yani yine demin yaptığımız gibi (166D)" cümlesi biraz önceki örnekteki yapıları kullanmak istediğinin açık bir ifadesidir. Veri grubunu incelerken, sorunun yazılması sirasinda, 100 ile $200 \mathrm{~km}$. aras1 mesafe ile ilgili bilgi verilmediğini fark edip, araştırmacıya soru yöneltmişlerdir. Aşağıdaki diyalogdan izlenebilen bu farkındalık ve 100 ile $200 \mathrm{~km}$ arasını atlama girişiminden (167 D), fonksiyonla ilgili ön bilgileri (birebir eşleme) kullandıkları anlaşılmıştır.

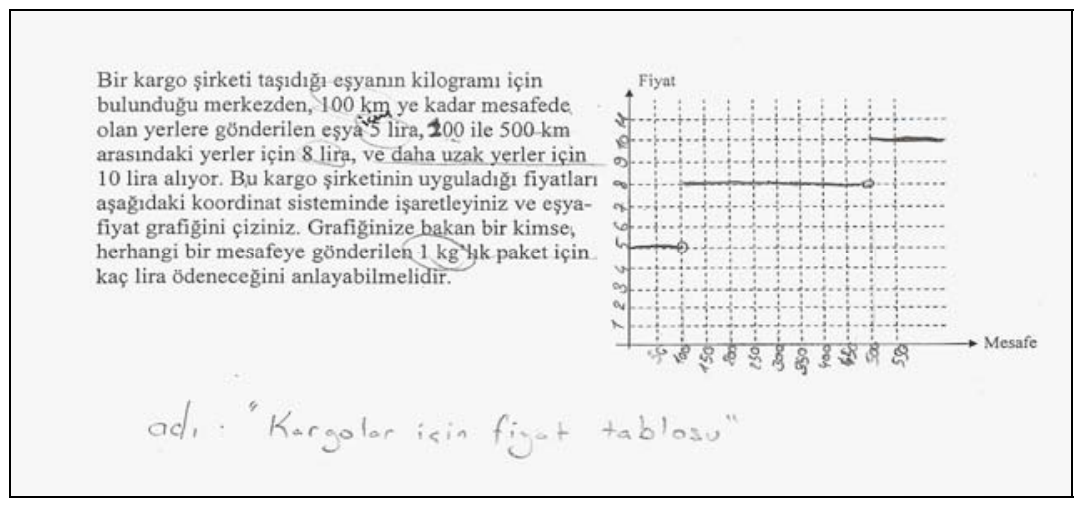

Şekil 3. Öğrencilerin Kargo Problemleri İçin Çizdikleri Grafik

$\mathrm{Bu}$ aşamadaki diyaloglar, öğrencilerin tanıma (167 D) ve kullanma (168 K. 170 D), ve (174 K, 173 D) eylemlerini kullandıklarını göstermiştir. $\mathrm{Bu}$ kısımdaki çalışmalar parçalı fonksiyonla ilgili olarak oluşturdukları yeni yapının sağlamlaşmasına (consolidation) yol açmış ve problemde eksik veri, konu yabancılığı olmasına rağmen grafiği kısa sürede doğru olarak çizmişlerdir (Şekil 3).

174 A: Son bir sorum var. Bu iki fonksiyon arasında bir benzerlik var mı? Buna benzer başka bir olay söyleyebilir misiniz? Olaylar birbirine benziyor mu? Kategori olarak buna bir ad verecek olsanız ne derdiniz? Öncekine fiyat tablosu demiştiniz.

$175 \mathrm{~K}:$ (...Birbirlerinin yüzlerine bakıyorlar) Mesafe tablosu,... Kargolar için mesafe tablosu....

Araştırmacının, öğrencilerin park ve kargo problemi ile ilgili grafik çizimlerinin arkasından bu fonksiyonlara bir sınıf ismi verip 
veremeyeceklerini sorması (174 A) soyutlamanın bir sınıf adı koyma düzeyine ulaşıp ulaşmadığı ile ilgilidir. Öğrenciler bu soruya, "Mesafe tablosu, kargolar için mesafe tablosu" şeklinde cevaplar vermişlerdir. Problemin konusunun düşündürdüğü bu adlar, öğrencilerin problemlerin özeline yöneldiklerini, soyutlama sürecinin doğasında bulunan kategorilemekten ve o kategoriyi adlandırmaktan hala uzak olduklarını göstermiştir.

Bu ikinci soru ile ilgili diyaloglarda bu problemin çözümünde epistemik eylemlerden tanıma ve kullanmanın hakim olduğunu göstermektedir.

Araştırmacı çalışmanın bu aşamasında öğrencilerden burada grafiklerini çizdikleri olaylara benzer olay bulmalarını ve elektronik mektup yoluyla kendisine iletmelerini istemiştir. Burada amaç; $\mathrm{RBC}+\mathrm{C}$ ye uygun olarak yapının pekişmesi için üzerinde daha çok düşünmelerini sağlamaktı. $\mathrm{D}$ ve $\mathrm{K}$ ayrı yazdıkları mektuplarda aşağıdaki üç soruyu araştırmacıya ulaştırmışlardır.

D: Şehir içinde görev yapan bir taksi şoförü; 1 km’ye kadar gittiği yol için 1 YTL, 3 km'ye kadar gittiği yol için 2 YTL, 10 km'ye kadar 6 YTL, 15 km'ye kadar 10 YTL, 20 km'ye kadar 16 YTL, $20 \mathrm{~km}$ ve daha üzeri km yol için 25 YTL alıyor. Bu koşula uyan bir yol - para grafiğgi çiziniz.

D: Yaz tatillerinde hizmette bulunan bir otel bir kişiye 12 saate kadar konaklama için 90 YTL, 24 saate kadar konaklama için 150 YTL, 2 güne kadar 250 YTL, 5 güne kadar 450 YTL, 7 güne kadar 750 YTL ve 10 güne kadar konaklama için 1000 YTL almaktadır. Buna göre bir kişi için konaklama süresi - para grafiğini çiziniz.

$\mathrm{K}$ : Elimizde aynı büyüklükte $5 \mathrm{~kg}$ 'lı torbalar var. İçine mal dolduracağız. Mal $5 \mathrm{~kg}$ veya daha az ise 1 torba, $5 \mathrm{~kg}$ 'dan itibaren $10 \mathrm{~kg}$ 'a kadar 2. torbaya geçilmesi gerek.

Öğrencilerin verdiği bu örnekler parçalı fonksiyonların doğru örnekleridir ve kategorik bir adlandırma yapamamalarına rağmen, zihinlerinde böyle bir sınıfın farkına vardıklarını göstermiştir.

\section{Demir Cubuklar Problemi}

Öğrenciler çalışmanın akıcılığ 1 içinde araştırmacının vermesini beklemeden üçüncü problemi istemişlerdir. Verilerde tam kısmı 4 olan veri sayıs1, öğrencilerin nokta yoğunluğundan yararlanarak fonksiyonun aralıklarda sürekli olduğunu sezdirmek amacıyla çok verilmişti.

Öğrenciler "okuyun” talimatı almadan üçüncü problemi okumaya başlamışlar ve grafiği çizmeye karşı istekli görünmüşlerdir. 
176 D: (sesli okuyor)

$177 \mathrm{~K}$ : Onları(sayıları kastediyor) geç, atla.

178 D: Tamam geçiyorum onları.

179 A: Burada sözü edilen masa gözünüzün önüne geliyor mu? Bu salonda öyle demir ayaklı bir masamız yok!

180 D,K: Evet.

181 D: Laboratuarlarda da olur.

$182 \mathrm{~K}$ : Şimdi bunlar birleşebiliyor mu? Aralarında kaynak yapılabiliyor $\mathrm{mu}$ ?

183 A: Hayır.

$184 \mathrm{~K}$ : Atıoruz.

Burada öğrencilerden Demet'in okurken Kemal'in (Demet'e) "sayıları geç, atla demesi", veri çokluğunun fonksiyonun çizime çok fazla katkı yapmayacağını fark etmesinden ileri gelmiştir. $\mathrm{Bu}$ durum verilerin niteliklerinin tanındı̆̆ının mükemmel ve şaşırtıcı bir göstergesidir. Demet' in "kaynak yapılabiliyor mu?" sorusu problemin içinde sunulduğu bağlamın iyi tanındı ğını göstermiştir.

Öğrenciler fonksiyonun çiziminde zorlanmamışlar ve Şekil 4'ten anlaşılacağı üzere verilerin birçoğunu kullanmadan doğru çizimi yapmayı başarmışlardır. 


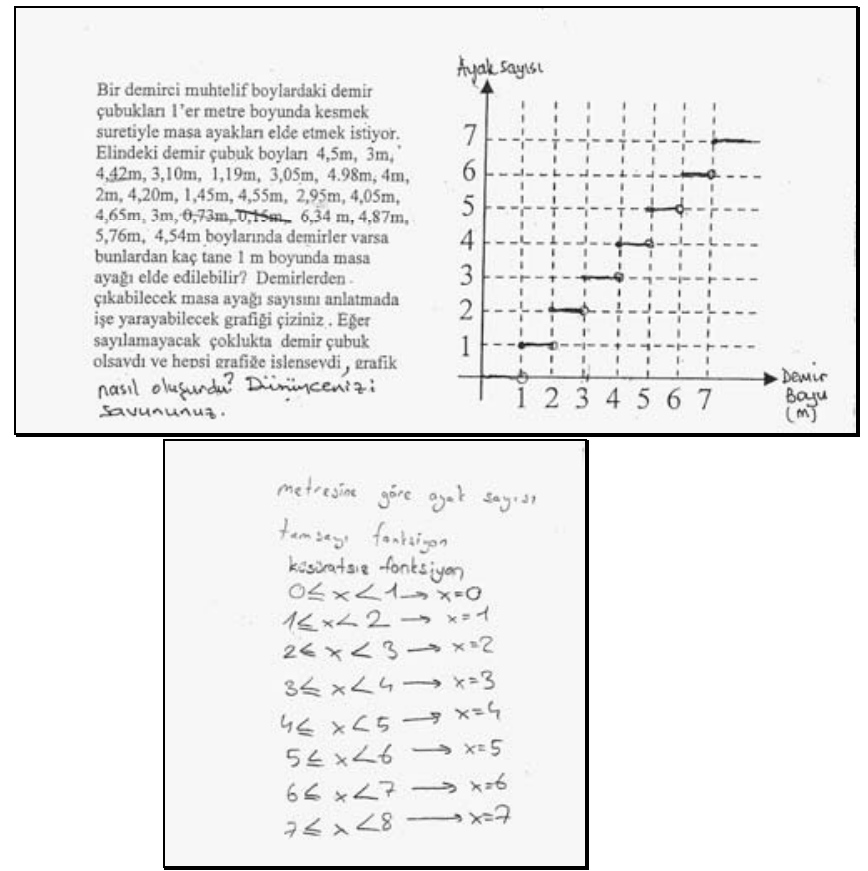

Şekil 4. Demet ve Kemal'in Demir Çubuklar Problemi İçin Çizdikleri Grafik ve Tanım Aralıkları.

Aşağıdaki diyaloglar çizim sırasında yaşananları göstermektedir.

185 D: O zaman şunları çizelim ( 1'den küçük olan çubuk boylarını soru metni üzerinde çizerek eliyorlar)

186 K: Şimdi öyle bir ayırmalıyız ki her bir yerinden...

187 A: Her birini değerlendirin, her bir değeri değerlendirin.

188 K: Bak şimdi nasıl olacak biliyor musun? 1 m'den küçüklerden ayak olmayacak. Yani burada (grafik) 1m olanlarla 1 ayak. Yani bunların kesiştiği noktalar dolacak(Kalemle işaret ediyor).

189 A: Doluluğun nerede olduğunu tam göster Kemal.

190 D: 2 metre olduğu zaman.

$191 \mathrm{~K}$ : Burası dolu olacak. (Grafik üzerinde yatay çizginin sol ucunu göstererek işaretliyor).

192 A: 2 ayak çıkıyor diyorsunuz.

193 K: Aynı şekilde. 
194 D: (Grafiği tamamlıyor).

Demet'in sayı ikililerini işaretleme (kullanma) isteği, Kemal tarafindan gereksiz bulunmuştur. $\mathrm{Bu}$ durum Kemal'in, noktaları işaretlemeden zihninde tasarlayıp kullanmış olduğunu göstermektedir.

Aşağıdaki diyalog çizimin tamamlanmasının ardından fonksiyonun adlandırılması ile ilgili tartı̧̧maları göstermektedir.

195 D: Değerlerini yazalım istersen. (Verileri, düzlemde işaretlemeyi kastediyor). bunları?

196 K: Fark etmez, belli oluyor zaten. Yazmamıza gerek var mı

197 D: 2,95'ten 2 ayak çıkar.

198 K: (Çizimi tamamlıyor).

199 A: Buna bir ad vermek gerekseydi ne derdiniz? Bunu nas1 buldunuz?

200 K: Diğerlerinin bazıları uzun bazıları kısa oldu. Bunda olmadı.

201 D: Ne diyebiliriz şimdi buna?

202 A: Hepsinde olup da bu grafikte çok açık olan bir şey var. Mesela 11,55 metreden, 11,99 metreden, 11,01 metreden...

203 D: 11, 11, 11.

$204 \mathrm{~K}$ : Başındaki tam sayı çıkıyor.

205 A: Buna bir ad koymalısınız.

$206 \mathrm{~K}$ : Metresine göre ayak sayısı.

207 A: 7,5 metrelik bir çubuktan kaç ayak çıkar?

$208 \mathrm{~K}: 7$.

209 D: Yani virgülden sonrasını saymayacak bir isim koymalıyız.

210 A: Aferin kızım.

211 D: Ne diyelim?

212 A: Virgülden sonrası atılan fonksiyon mu diyelim?

213 D: Olabilir aslında.

214 A: Düşününüz, 4,42 kaça eşleniyor? 
$215 \mathrm{D}, \mathrm{K}: 4$.

216 A: 3,1' e 3. Başka 4,54'e 4. Orada bir düşüş var. Aklınıza gelen şeyleri özgürce söyleyin. Mesela ne denebilir?

217 D: Ne denebilir?

218 A: Sayılar küsuratlarını terk ederek bir değere ulaşıyorlar, değil mi? Hangi değere eşleniyorlar?

$219 \mathrm{~K}$ : Başındaki değere.

220 D: Başındaki tamsayıya, tamsayının küsuratsız fonksiyonu.

221 A: Yani, "Küsuratsız fonksiyon" mu diyorsunuz?

222 D: Küsuratsız fonksiyon, gerçekten güzel.

223 A: Küsuratsiz olunca ne oluyor? Geriye ne kalıyor?

224 D: Yani virgülden sonrasını saymıyoruz. Tamsayının küsuratsız fonksiyonu.

Öğrenciler "küsuratsız fonksiyon”, "tamsayının küsuratsız fonksiyonu" adlarını önermişlerdir. Küsuratsız fonksiyonda, sayının ondalık kısmını atmak suretiyle elde edildiğini belirtmeleri fonksiyonu belirleyen temel özelliğinin farkında olduklarını, yeni bir yapı oluşturduklarını göstermektedir.

$225 \mathrm{~A}: \mathrm{Bu}$ tür şeylerin öğretim programında yer alması uygun mudur? Matematik derslerinde böyle şeylerle meşgul olunmalı mıdır?

$226 \mathrm{~K}$ : Yani olmalı çünkü bunlar hesaplanırken mesela ilk önce 2 metreliği hesaplayacak, 3 metreliği hesaplayacak.

227 A: Yani hayatta böyle olaylar var. Bu üç örnek içinde en çok hangisi hoşunuza gitti? Hangisi daha çok içinize sindi? Hangisi daha karş1laş1labilir günlük hayatta?

228 D: Şu araba şeyi, problemi.

$229 \mathrm{~K}$ : Araba problemi herkesin önüne çıkabilir.

230 A: Bunun matematiksel tanımına ulaşabilir misiniz?

231 D,K: ... (birbirlerine ve araştırmacıya bakıp sustular).

Öğrencilerin çizdikleri grafiğin altına yazdıkları soldan kapalı sağdan açık aralıkları tamsayıya eşlemeleri de tam değer fonksiyonunu belirleyen özellikleri öğrendiklerini, başka bir deyişle kavramı soyutladıklarını 
göstermiştir. Burada aralıkları doğru olarak göstermeleri ve Şekil 4'te gösterilen eşitsizlik notasyonlarını doğru kullanmaları daha önce edinmiş oldukları yapılarla ilgilidir. Bu beceriler kullanma eylemini gösterdiklerini anlatmaktadır. Öğrencilerin eşitsizlik notasyonlarını kullanmaları Tam Değer Fonksiyonu hakkında oldukça anlamlı bir bilgi oluşturduklarını göstermiştir. $\mathrm{Bu}$ denli başarılı bir çalışmaya rağmen öğrencilerin, bir tanım veremedikleri (231 D,K) yani bu tür fonksiyonları yeni bir fonksiyon sinıfı olarak algılayamadıkları gözlenmiştir.

\section{TARTIŞMA ve SONUÇ}

$\mathrm{Bu}$ çalışmanın temel hedefi, lise öğrencileri için Tam Değer Fonksiyonunun öğretiminde işe yarayacak bir öğretim modeli önermek ve onu tartışmaktı. Bu amaçla, henüz Tam Değer Fonksiyonu ile tanışmamış bir öğrenci çiftine, sıralı yöneltilecek üç soru hazırlanmış ve öğretim yapılmıştır. Daha sonra bu öğretim içinde öğrencilerin Tam Değer Fonksiyonunu ne ölçüde öğrendiği (soyutlamanın gerçekleşip gerçekleşmediği) incelenmiştir.

Öğretimde kullanılan sorular bazı sinırlılıklarla birlikte öğretim için uygun bir materyal oluşturmuş ve Tam Değer Fonksiyonunun kavranması için yeterli olmuştur. Çalışmanın başında referans alınan hususlar itibariyle çalışma şöyle değerlendirilebilir:

\section{Problem Çözme Tabanlı Çalışma ve Gerçek Problemlerin Aracılı̆̆ı}

$\mathrm{Bu}$ çalışmada problem çözme tabanlı bir öğretim yapılmış ve ilk soru olarak yöneltilen "park problemi" nin anlaşılmasında yaşanan duraksama göz ardı edilecek olursa, öğrenciler problemlerin üçüne de ilgi göstermiş ve sonuçlandırmak için çaba harcamışlardır.

Park problemindeki veriler, bir park tarifesinden alınmıştır ve öğrencilerin bir otoparkta ödeme yapmamış olsalar bile, ödemeye tanık olmuş olmaları, problemin bir gerçek yaşam problemi olarak değerlendirilebilmesi için yeterli sayılmıştır. $\mathrm{Bu}$ durum hala De Corte (2004)'nin matematiği tanımlarken kullandığı gerçekliğin modellenmesi deyimi ile tam örtüşmemektedir. Gerçekliğin modellenebilmesi için, matematikleştirmenin esas alınması (Gravemeijer, 1990) ve öğrencilerin park etme tarifesi hazırlama güçlüğü ile karşı karşıya bırakılması, sonra onun üzerinde çalışmak suretiyle, parçalı fonksiyonu tanımlamaları, grafiğini çizmeleri gerekmektedir. Bu durum dikkate alınarak, yeni araştırmaların planlanması mümkündür ve böyle planlanmış araştırmalar, öğretimi yapılandırmacı yaklaşımın yanı sıra GME'ye uygunluk bakımından da test etmiş olur. 
İkinci problem (kargo problemi), birinci problemde oluşturulan yapıların kullanılması ve kırılgan yapılarının giderilmesi amaciyla sorulmuştur. Bu iki problemin çözümünden, Tam Değer Fonksiyonu için bir taban bilgi oluşturmak hedeflenmişti. Öğrenciler çalışmanın bu aşamasında, daha önce edindikleri fonksiyon kavramı sürekli bir çizgi olarak algılanmış iken (Şekil 1), onun parçalı da olabileceğini fark etmişlerdir. Böylece zihinlerindeki fonksiyon kavramında bir genişleme ortaya çıkmış olup, bu durum yeni bir yapı oluşturdukları şeklinde nitelenebilir. Tam Değer Fonksiyonu için yöneltilen, "demir çubuklar problemi”ni çözme sırasındaki çalışma sürati ve diyaloglar içinde görülen tanıma ve kullanma eylemleri (188K, 203 D, 204K, 208 K, 209D, 219 K, 220D) ilk iki sorunun üçüncü problem için uygun ön yapılar oluşturduğunu ve bunların kullanıldığını göstermektedir. Öğrenciler bu problemlerden ilkini hayatla daha çok ilgili bulmuşlardır (228D, 229K). Öğretimdeki sıranın bu şekilde seçilmesi ile öğrencinin hayatında daha az rastlanan matematiksel uygulamaları, çok rastlananların bir uzanımı haline getirmek amaçlanmış ve bunun gerçekleştiği görülmüsştür. Buna bağlı olarak 2. ve 3. problemler birinciye göre daha kısa sürede (8d, 6d) çözülmüş çalışma sırasında öğrencilerde istek ve heyecan artışı gözlenmiştir. Problemlerin her biri ile ilgili öğretim diyalogları, öğrencilerin kendi aralarında tartışarak bilgiyi oluşturduklarını göstermektedir. Bunlar dikkate alındığında; öğretimin, problem çözme tabanlı olarak sürdürüldüğ̈̈ ve yapılandırmacı öğrenmeye uygun olarak gerçekleştiği söylenebilir.

\section{Soyutlamanın Gerçekleşmesi}

$\mathrm{Bu}$ çalışmada problemlerin sıralanışına uygun olarak parçalı fonksiyon ve Tam Değer Fonksiyonu kavramlarının bir ölçüde soyutlandığ 1 anlaşılmaktadır. Öğrenciler, fonksiyonlara ad vermeyle ilgili $152 \mathrm{~K}, 175 \mathrm{~K}$ ve 206K nolu diyaloglarda "fiyat tablosu", "mesafe tablosu" ve "metresine göre ayak sayısı" şeklinde adlar önermişlerdir. Her bir çalışmanın arkasından öğrencilerden fonksiyona bir ad vermeleri istendiğinden öğrenciler, problemlerin konularına odaklanmışlardır. Bu durum öğrencilerin ilk iki problemin çözümüyle ilgili "parçalı fonksiyon" adını veya bunu düşündüren başka bir ad kullanmalarını muhtemelen önlemiştir. Bilişsel psikologların soyutlama için verdikleri, matematiksel nesneleri özelliklerine göre ilişkilendirmek ve daha ileri bir matematiksel nesneye ulaşmak (Hershkowitz vd., 2001) şeklindeki tanımın içeriğine uygun soyutlamanın bu çalışmada gerçekleşmediği görülmektedir.

Tam Değer Fonksiyonunu adlandırma ile ilgili tartışmalarda, parçaların boylarının aynı olduğunu (202 A, 203D, 204K) fark etmişler ve tam değer adına yakın düşen "küsuratsız fonksiyon" (220D, 221A, 222D, 223A, 224D) 
adını önermişlerdir. $\mathrm{Bu}$ durum soyutlamanın bir göstergesi olarak değerlendirilebilir. Öğretimin lise öğrencilerinde, böyle bir fonksiyon grubunun farkındalığını yaratıp yaratmayacağı hususu, bu araştırmanın devamında uygun başka problemlerin (örneğin not aralıklarının AA, BA,... gibi harflerle eşlenmesi v.s.), öğretimi ile mümkün olabilir. Bu durum başka bir araştırmanın konusu olabilir. Yürütülen çalışma bu farkındalığı ortaya koyamamakla; soyutlamayl, bilişsel ve diyalektik yaklaşımın birleşik formunun daha mükemmel açılayabileceğini işaret etmiştir.

Soyutlamanın epistemik eylemleri olarak bilinen tanıma, kullanma ve oluşturmanın doğrusal olmayıp (Özmantar, 2004; Dreyfus, 2007; Yeşildere ve Türnüklü, 2008) birbiri içine yuvalanmış yapısı bu çalışmada da doğrulanmıştır. Sürecin analizi soyutlama süreci ile ilgili açıklama diyalektik yaklaşımı destekleyen Hershkowitz vd. (2001); Özmantar (2004); Monaghan ve Özmantar (2006); Dreyfus (2007); Yeşildere ve Türnüklü’nün (2008) çalışmaları ile tutarlı çıkmış ve soyutlamanın diyalektik doğası bu çalışmada da doğrulanmıştır. Buna örnek olarak $124 \mathrm{~K}$ tanıma ve kullanma (tabloyu okuma ve anlamlandirma), 125 D kullanma (verileri kullanma), $133 \mathrm{D}$ ve $135 \mathrm{D}$ oluşturma (parçalı oluşunun farkına varma),138 K kullanma (analitik düzlemin noktaları ile reel sayı ikililerini eşleme), $160 \mathrm{D}$ kullanma ve oluşturma (koordinat eksenlerindeki aralıklara değer atama... vs.) gösterilebilir.

Sonuçların, program geliştirme için de vereceği ipuçları vardır.

$\mathrm{Bu}$ çalışma doğal bir olgu veya olayın (realitenin) temele alınmasının öğretimde niteliği arttırabileceğini işaret etmiştir. Doğal model bulmak her zaman kolay değildir ve güçlük, özellikle atanmış değerler içeren fonksiyonların öğretimi sırasında fonksiyon için model bulmada gözlenir. Örneğin Tam Değer Fonksiyonunun üçüncü bölgedeki kısmı, doğal bir olayla eşlenmez. Fonksiyonun bu parçası, doğal bir olayın görüntüsü olarak kavranan birinci bölgedeki parçasının düşündürdüğü yani uzanımında elde edilecek kısmı olarak, yine bu bilginin üzerine inşa edilebilir. Buna örnek olarak doğal bir olayla eşlenmeyen durumlara bir başka örnek olarak işaret fonksiyonu verilebilir. İşaret fonksiyonu öğretimi üzerinde çalışırken nesneleri tasnif edip, bir kısmını -1 ile gösterme, doğal bir olayın görüntüsü değil, bir atamadır. Öğrencilerin bu tür atamalara anlam verebilmesi için, öncelikle doğal olayların görüntüsü olan fonksiyonları, sonra doğal bir olaya eşlenemeyen fonksiyonları çalışmaları uygun düşebilir. Bu durum, hemen her fonksiyon türü için bu çalışmanın bir benzerine olan ihtiyacı ortaya koymaktadır. 
Geleneksel sistemdeki "Tanım ve Değer Kümesi” tanımından başlayan öğretim yerine, burada örneklendiği gibi gerçek olaylar üzerinde çalışmak ve onların matematikleştirilmesini sağlamak, soyutlamayı kolaylaştırabilir. $\mathrm{Bu}$ tarz çalışma sürekli olarak öncekilerin kullanımına yol açacağ önce edinilmiş yapıların güçlenmesine yol açabilir. Bu çalışma, Tam Değer Fonksiyonu kavramını parçalı fonksiyon kavramı üzerine inşa etmekle, öğretimde konu sırasının önemini desteklemiştir. Fonksiyonlar üzerinde yürütülebilecek benzer araştırmalar mevcut lise programlarında, doğrusal, ikinci dereceden, trigonometrik, periyodik, üstel, logaritma, işaret, Tam Değer, parçalı fonksiyonlar (Milli Eğitim Bakanlığı, 2008) şeklindeki konu sırasının yeniden gözden geçirilmesi ihtiyacını ortaya koyabilir. Ayrıca soyutlamanın epistemik eylemlerden özellikle oluşturmaya olan katkısından ötürü bu çalışma, problem çözme becerilerinin önemini de ortaya koymaktadır. Özellikle gerçek ve rutin olmayan problemlerle yürütülen bu çalışma, öğretimde materyal olarak kullanma, matematiksel bilgilerin daha nitelikli olarak oluşturulabilmesine katkı sağlayacağını ortaya koymaktadır.

\section{KAYNAKLAR}

Baki, A. ve Öztekin B. (2003) Excel Yardımıyla Fonksiyonlar Konusunun Öğretimi, Kastamonu Eğitim Dergisi, Cilt:11 No:2, 325-338.

Bikner-Ahsbahs, A. (2004) Towards The Emergence Of Constructing Mathematical Meanings, Proceedings of the 28th Conferance of the International Group for the Psychology of Mathematics Education, Vol 2, pp, 119-126.

Cobb, P. (1994) Where is the Mind? Constructivist and Sociocultural Perspectives on Mathematical Development, Educational Researcher, Vol. 23, No.7, pp13-20.

Davydov, V. V. (1990) Types Of Generalization In Instruction: Logical and Psychological Problems In The Structuring Of School Curricula. In J. Kilpatrick (Ed.) \& J. Teller (Trans.), Soviet Studies in Mathematics Education: Vol. 2, NCTM.

De Corte, E. (2004) Mainstreams and Perspectives in Research on Learning Mathematics From Instruction, Applied Psychology, Vol.53, pp, 279-310.

Dede, Y. (2004) Öğe Gösterim Teorisi'nin Bir Uygulaması: Fonksiyon Kavramının Öğretimi, Gazi Üniversitesi Kırşsehir Eğitim Fakültesi Dergisi, Cilt 5, Say1 2, sf. 287-297.

De Lange. J. (1996) Using and Applying Mathematics in Education. In A. J. Bishop, K. Clements. C. Keitel. J. Kilpatrick. \& C. Laborde (Eds.), International Handbook of Mathematics Education (Part 1, pp. 49-97), The Netherlands: Kluwer. 
Doolittle, , P. E. (1999) Constructivism and Online Education, IN: Online Conference on Teaching Online in Higher Education; Virginia Polytechnic Institute \& State University.

Dreyfus, T. (2007) Processes of Abstraction in Context the Nested Epistemic Actions Model, EBSCO veritabanından 20.06.2008 tarihinde alınmıştır. Web üzerinde: http://escalate.org.il/construction_knowledge/papers/dreyfus.pdf .

Fosnet, C.T \& Perry, R,S (2007) Oluşturmacılık: Psikolojik Bir Öğrenme Teorisi, C.T.Fosnet (Ed.), (S. Durmuş Çev.) ConstructivismOluşturmacılık, Teori, Perspektifler ve Uygulama, (2. Baskı) İstanbul: Nobel Yayın Dağıtım.

Glasersfeld, E.V. (2007) Giriş: Oluşturmacılı̆̆ın Yansımaları, C.T.Fosnet (Ed.), (S. Durmuş Çev.) Constructivism-Oluşturmacıllk, Teori, Perspektifler ve Uygulama, (2. Bask1) İstanbul: Nobel Yayın Dağıtım.

Gravemeijer, K. (1990) Context Problems and Realistic Mathematic Instruction, Gravemeijer, K., Hauvel M. V. \& Streefland, L. (Ed.) Contexts Free Productions Tests and Geometry in Realistic Mathematics Education, the State University of Utrecht, Netherlands.

Gravemeijer, K. (1994) Developing Realistic Mathematics Education, Freudenthal Instute, Utrecht, Netherlands.

Güveli, E. ve Güveli, H. (2002) Lise 1 Fonksiyonlar Konusunda Web Tabanlı Örnek Bir Öğretim Materyali, V. Ulusal Fen Bilimleri ve Matematik Ĕ̈itimi Kongresi (Bildiriler Kitabı).

Hauvel - Panhuizen, M. (1996) Assessment and Realistic Mathematics Education, Technipress, Netherlands.

Hershkowitz, R., Schwarz, B. B. \& Dreyfus, T. (2001) Abstraction in Contexts: Epistemic Actions, Journal for Research in Mathematics Education, 32 (2), 195-222.

Karasar, N. (2007) Bilimsel Araştırma Yöntemi Kavramlar, İlkeler, Teknikler, (17. Baskı), Ankara: Nobel Yayın Dağıtım.

Karataş, İ. ve Güven, B. (2004) Fonksiyon Kavramının Farklı Öğrenim Düzeyinde Olan Öğrencilerdeki Gelişimi, Eurasian Journal of Educational Research, 16 pp.

Koçbeker, B,N. ve Saban, A. (2005) Otistik Bir Çocuğun Yabanc1 Dil Öğrenimine İlişkin Örnek Olay İncelemesi, Çukurova Üniversitesi Sosyal Bilimler Enstitüsü Dergisi, Say1 14, sayfa 401-428. Ulakbim veritabanından 23.06.2008 tarihinde alınmıştır. Web üzerinde: http://www.sosyalbil.selcuk.edu.tr/sos mak/makaleler\%5CAhmet $\% 20$ SA BAN\%20Beyhan\%20Nazl\%C4\%B1\%20KO $\%$ C3\%87BEKER\%5C401428.pdf. 
Lincoln, Y.S. \& Guba, E.G. (1985) Naturalistic Inquiry, Beverly Hills, CA, Sage.

MEB, http://ogm.meb.gov.tr/ 23.06.2008 tarihinde elde edilmiştir.

Monaghan, J \& Özmantar, M.F. (2006) Abstraction and Consolidation, Educational Studies in Mathematics, Springer. EBSCO veritabanından 20.06.2008 tarihinde alınmıştır. Web üzerinde: http://www.springerlink.com/content/c134370723467362/fulltext.pdf.

Özmantar, M.F. (2004) McNamara, O. (Ed.) Proceedings of the British Society for Research Into Learning Mathematics 24(2). EBSCO veritabanından 20.06.2008 tarihinde alınmıştır. Web üzerinde: http://www.bsrlm.org.uk/IPs/ip24-2/BSRLM-IP-24-2-14.pdf.

Özmantar, M.F. \& Monaghan, J. (2007) A Dialectical Approach to the Formation of Mathematical Abstractions, Mathematics Education Research Journal, Vol. 19, No. 2, pp. 89-112.

Schoenfeld, A.H. (1988) When Good Teaching Leads to Bad Results: The Disasters of "Well Taught" Mathematics Courses", Educational Psychologist, Vol.23, No. 2.

Tanışl1, D. (2008) İlköğretim Beşinci Sınıf Öğrencilerinin Örüntülere İlişkin Anlama ve Kavrama Biçimlerinin Belirlenmesi. Yayınlanmamış Doktora Tezi, Eğitim Bilimleri Enstitüsü, Anadolu Üniversitesi, Eskişehir.

Tomic, W. \& Nelissen, J. M. (1998) Representations in Mathematics Education. Hearken, ERIC Document Reproduction.

Verdolaege, S. \& Woods, K. (2008) Counting With Rational Generating Functions, Science Direct, Elsevier Journal of Symbolic Computation, Vol. 43, pp. 75-91

Yeşildere, S. (2006) Farklı Matematiksel Güce Sahip İlköğretim 6, 7, ve 8. Sınıf Öğrencilerinin Matematiksel Düşünme Ve Bilgi Oluşturma Süreçlerinin İncelenmesi, Yayınlanmamış Doktora Tezi, Dokuz Eylül Üniversitesi, Eğitim Bilimleri Enstitüsü, İzmir.

Yeşildere, S. ve Türnüklü, E.B. (2008) İlköğretim Sekizinci Sınıf Öğrencilerin Bilgi Oluşturma Süreçlerinin Matematiksel Güçlerine Göre İncelenmesi, Uludă̆ Üniversitesi Ĕgitim Fakültesi Dergisi, Cilt 22, Say1 1.

Yıldırım, A. ve Şimşek, H. (2006) Sosyal Bilimlerde Nitel Araştırma Yöntemleri, (5. Baskı), Ankara: Seçkin Yayıncılık.

Yıldırım, C.(1988) Matematiksel Düşünme, 1. Baskı, İstanbul: Remzi Kitabevi. 